\title{
Trends and abrupt changes in 104 years of ice cover and water temperature in a dimictic lake in response to air temperature, wind speed, and water clarity drivers
}

\author{
Madeline R. Magee ${ }^{1}$, Chin H. Wu ${ }^{1}$, Dale M. Robertson ${ }^{2}$, Richard C. Lathrop ${ }^{3}$, and David P. Hamilton ${ }^{4}$ \\ ${ }^{1}$ Civil and Environmental Engineering, University of Wisconsin-Madison, Madison, Wisconsin, USA \\ ${ }^{2}$ Wisconsin Water Science Center, US Geological Survey, Middleton, Wisconsin, USA \\ ${ }^{3}$ Center for Limnology, University of Wisconsin-Madison, Madison, Wisconsin, USA \\ ${ }^{4}$ Environmental Research Institute, University of Waikato, Hamilton, New Zealand
}

Correspondence to: Chin H. Wu (chinwu@engr.wisc.edu)

Received: 10 November 2015 - Published in Hydrol. Earth Syst. Sci. Discuss.: 19 January 2016

Revised: 19 April 2016 - Accepted: 21 April 2016 - Published: 3 May 2016

\begin{abstract}
The one-dimensional hydrodynamic ice model, DYRESM-WQ-I, was modified to simulate ice cover and thermal structure of dimictic Lake Mendota, Wisconsin, USA, over a continuous 104-year period (1911-2014). The model results were then used to examine the drivers of changes in ice cover and water temperature, focusing on the responses to shifts in air temperature, wind speed, and water clarity at multiyear timescales. Observations of the drivers include a change in the trend of warming air temperatures from $0.081{ }^{\circ} \mathrm{C}$ per decade before 1981 to $0.334^{\circ} \mathrm{C}$ per decade thereafter, as well as a shift in mean wind speed from $4.44 \mathrm{~m} \mathrm{~s}^{-1}$ before 1994 to $3.74 \mathrm{~m} \mathrm{~s}^{-1}$ thereafter. Observations show that Lake Mendota has experienced significant changes in ice cover: later ice-on date( 9.0 days later per century), earlier ice-off date (12.3 days per century), decreasing ice cover duration ( 21.3 days per century), while model simulations indicate a change in maximum ice thickness $(12.7 \mathrm{~cm}$ decrease per century). Model simulations also show changes in the lake thermal regime of earlier stratification onset (12.3 days per century), later fall turnover ( 14.6 days per century), longer stratification duration (26.8 days per century), and decreasing summer hypolimnetic temperatures $\left(-1.4^{\circ} \mathrm{C}\right.$ per century). Correlation analysis of lake variables and driving variables revealed ice cover variables, stratification onset, epilimnetic temperature, and hypolimnetic temperature were most closely correlated with air temperature, whereas freeze-over water temperature, hypolimnetic heating, and fall turnover date were more closely correlated with wind speed.
\end{abstract}

Each lake variable (i.e., ice-on and ice-off dates, ice cover duration, maximum ice thickness, freeze-over water temperature, stratification onset, fall turnover date, stratification duration, epilimnion temperature, hypolimnion temperature, and hypolimnetic heating) was averaged for the three periods (1911-1980, 1981-1993, and 1994-2014) delineated by abrupt changes in air temperature and wind speed. Average summer hypolimnetic temperature and fall turnover date exhibit significant differences between the third period and the first two periods. Changes in ice cover (ice-on and iceoff dates, ice cover duration, and maximum ice thickness) exhibit an abrupt change after 1994, which was related in part to the warm El Niño winter of 1997-1998. Under-ice water temperature, freeze-over water temperature, hypolimnetic temperature, fall turnover date, and stratification duration demonstrate a significant difference in the third period (1994-2014), when air temperature was warmest and wind speeds decreased rather abruptly. The trends in ice cover and water temperature demonstrate responses to both long-term and abrupt changes in meteorological conditions that can be complemented with numerical modeling to better understand how these variables will respond in a future climate. 


\section{Introduction}

Many studies have shown that lake temperatures and ice cover can strongly affect water chemistry, individual organism physiology, population abundance, community structure, and food-web dynamics (King et al., 1997; Schindler et al., 1990). Air temperature (Findlay et al., 2001; Lynch et al., 2015), wind speed (Brown et al., 1993; Lynch et al., 2015), and water clarity (Arhonditsis et al., 2004b; Lathrop et al., 1996) are important factors driving these lake ecosystem properties. Understanding how lakes respond to changes in these drivers is of great interest to predict how lakes may change in the future (Fang and Stefan, 2009; Magnuson et al., 1997; Robertson, 1989). The response of lake ice and water temperature to long-term changes in air temperature and wind speed is integral to assess potential impacts of climate change on lake ecology.

Over the past 100 years, climate has been changing and will continue to change (IPCC, 2013). Globally averaged combined land and ocean surface temperature data show a linear warming trend of $0.85^{\circ} \mathrm{C}$ from $1880-2012$ (IPCC, 2013). This warming was most pronounced from 19792012, greater than $0.25^{\circ} \mathrm{C}$ per decade (Hartmann et al., 2013). Increases in air temperature alter the ice cover of lakes (Butcher et al., 2015; Magnuson et al., 2000; Robertson et al., 1992) and affect their thermal structures (Robertson and Ragotzkie, 1990), evidenced by increasing epilimnetic temperatures (Arhonditsis et al., 2004a; Dobiesz and Lester, 2009; Schindler et al., 1990), warming of the lake surface temperature (Schneider and Hook, 2010; Shimoda et al., 2011), increasing temperature gradient across the thermocline (Robertson and Ragotzkie, 1990; Wilhelm and Adrian, 2008), changing thermocline depth (King et al., 1997; Schindler et al., 1990), advancing the onset of summer stratification (Austin and Colman, 2007), delaying fall turnover (King et al., 1997), increasing the strength of thermal stratification (Rempfer et al., 2010), and prolonging the stratified period (Robertson and Ragotzkie, 1990; Wilhelm and Adrian, 2008).

Trends in wind speed over the last 30-50 years have been reported in several studies that have analyzed historical wind speed records across the globe (Jiang et al., 2009; Wan et al., 2010). Klink (2002) examined 22- to 35-year records (ranging between 1959 and 1995) of wind speed at seven stations in and around Minnesota and found decreasing annual wind speeds at five of the seven stations. Pryor et al. (2009) reported that the 50th and 90th percentile annual wind speeds over the period 1973-2005 across most of the US have also decreased. Decreased wind speeds increase thermal stratification and can reduce whole-lake average temperature (Tanentzap et al., 2008). Interestingly, an opposing trend (increasing wind speed) has been observed in Lake Superior, North America, where the lake surface temperatures have been warming faster than air temperatures (Austin and Colman, 2007). Desai et al. (2009) suggest that the larger increase in water temperatures than air temperatures reduced the air-water temperature gradient and destabilized the atmospheric surface layer above Lake Superior, which resulted in increasing wind speed at a rate of nearly $5 \%$ per decade. Differences in wind-driven mixing may explain different temperature responses of hypolimnetic waters in large and small lakes (Winslow et al., 2015). While the importance of wind in lake heat transfer (Fu et al., 2009; Read et al., 2012), mixing, and thermal structure (Desai et al., 2009; Schindler et al., 1990) has been recognized, studies on the effects of wind speed alterations on seasonal ice cover and thermal structure of lakes are still rare.

Water clarity, which controls the amount of solar radiation penetrating into a lake, plays an important role in heat budgets in lakes. Increased water clarity can result in warmer deep waters (Stefan et al., 1996), while reduced light penetration can result in decreased mixing depth and cooler deep waters (Hocking and Straškraba, 1999; Tanentzap et al., 2008). Previous studies have also shown that increased water clarity was correlated with deeper mixed-layer depth (Fee et al., 1996; Mazumder and Taylor, 1994; Schindler et al., 1996) and increased hypolimnetic heating rate (Yan, 1983). Water clarity has important consequences for photosynthesis and vertical distribution of biota. Accompanied by a warming climate, increased evaporation and changes in precipitation patterns can alter the inputs of nutrients and dissolved organic carbon (DOC) into lakes, resulting in changes in water clarity (Schindler et al., 1990, 1996).

Abrupt shifts, rather than linear changes, can occur in both climate and lake variables over long timescales. In the past, the majority of referenced studies used some form of linear regression analysis to look for changes, which assumes that lakes undergo monotonic changes over time (Van Cleave et al., 2014). This assumption can mask the occurrence of step changes (Liu et al., 2013; North et al., 2013) and can hide the underlying mechanisms that are responsible for the changes (North et al., 2014). As noted in other studies (Mueller et al., 2009; Van Cleave et al., 2014), long-term changes in lake thermodynamic variables can be associated with a pronounced, nonlinear step change that indicates a rapid switch between stable states or regimes (North et al., 2013; Rodionov, 2004; Scheffer et al., 2001). Identifying this type of abrupt change in climate drivers and corresponding abrupt or gradual change in lake variables may shed light on the role of changing climate on the corresponding ecosystem.

The purpose of this study is to investigate how long-term changes in air temperature, wind speed, and water clarity affect the ice cover and thermal structure of a dimictic Lake Mendota, Wisconsin, USA during the past century using a long-term 104-year simulation model. We hypothesize that changes in lake ice cover (ice-on and ice-off dates, ice cover duration, and maximum ice thickness) and thermal structure (stratification onset, fall turnover date, stratification duration, water temperatures, and hypolimnetic heating) variables may be characterized by periods of abrupt change rather than 
gradual trends, based on observations of rapid change in the climate drivers of air temperature and wind speed. To address this, a one-dimensional hydrodynamic model with ice cover is employed to simulate long-term (1911-2014) ice cover and water temperature in the lake. With the knowledge of lake responses to these past conditions, we aim to reveal how lakes might respond to future changes in air temperature, wind speed, and water clarity.

\section{Methods}

\subsection{Hydrodynamic model}

An ice and snow model was added to the DYRESM-WQ model (Hamilton and Schladow, 1997), a physically based one-dimensional hydrodynamic model for simulating vertical mixing and advective transport in lakes and reservoirs. The resulting model, DYRESM-WQ-I (Hsieh, 2012), is used to simulate daily changes in the vertical distribution of water temperature and ice cover in Lake Mendota from 19112014. In this model, the lake is represented by a series of Lagrangian horizontal layers with uniform properties that may change in elevation and thickness in response to inflows/outflows and surface mass fluxes (evaporation and precipitation). Layer thickness is updated using an algorithm to give appropriate vertical density resolution at each time step. Mixing in the model is represented by merging the layers when the sum of available turbulent kinetic energy (TKE) produced by wind stirring, convective turnover, and shear stress exceeds the potential energy required to mix the adjacent layer below. Hypolimnetic mixing is modeled with an eddy diffusivity coefficient, which is a function of the dissipation of TKE and strength of stratification. More detailed descriptions of the simulation of water temperature and mixing are provided by Imberger and Patterson (1981).

The ice model is based upon the MLI model of Rogers et al. (1995) with alterations to two-way coupling of the watercolumn dynamics to the ice model and the addition of timedependent sediment heat flux for all horizontal layers. Ice growth in the model is based upon a quasi-steady state assumption that the timescale for heat conduction through the ice is short relative to the timescale of meteorological forcing (Patterson and Hamblin, 1988; Rogers et al., 1995). This assumption is valid under a Stefan number $<0.1$ (Hill and Kucera, 1983). The ice module is applied when the simulated surface water temperature first drops below $0^{\circ} \mathrm{C}$; the initial ice thickness is set to a value of $5 \mathrm{~cm}$ to address effects of partial ice cover (Patterson and Hamblin, 1988; Vavrus et al., 1996). Upward conductive heat flux between ice/snow cover and the atmosphere, $q_{0}$, is determined by numerically solving the quasi-steady state heat conduction equations (Rogers et al., 1995) and assigning appropriate boundary conditions to the water, ice, and atmospheric interfaces. At the ice (or snow) surface, a heat flux balance provides the condition for surface melting, and accretion or ablation of ice is determined through the heat flux at the ice-water interface. Imbalance between heat conduction through ice and the heat flux from the water to the ice gives the rate of change of ice thickness at the ice-water interface. Snow conductivity is estimated from its density using an empirical equation (Ashton, 1986), and snow compaction is based on an exponential decay formula (McKay, 1968), with snow compaction parameters based on air temperature and snowfall/rainfall (Rogers et al., 1995). Snow (white) ice is generated in response to flooding, when the mass of snow that can be supported by the ice cover is exceeded. The uppermost solid layer of ice or snow is adjusted in thickness at the end of each $1 \mathrm{~h}$ model time step according to the balance of the heat budget. When ice thickness decreases to less than $5 \mathrm{~cm}$, open water conditions are restored.

Sediment heat flux, the main external source of heat after freezing, is important to water temperatures beneath ice cover (Ellis et al., 1991). Sediment heat flux (Fang and Stefan, 1996a) is included as a source/sink term for each Lagrangian layer to closely simulate under-ice water temperatures. A simple diffusion relation (Rogers et al., 1995) is used to estimate heat transfer from the sediments to the water column, $q_{\text {sed }}$ :

$q_{\mathrm{sed}}=K_{\mathrm{sed}} \frac{\mathrm{d} T}{\mathrm{~d} z}$,

where $K_{\text {sed }}$ is the sediment conductivity $\left(=1.2 \mathrm{~W} \mathrm{~m}^{-1}{ }^{\circ} \mathrm{C}^{-1}\right) . \quad \mathrm{d} T / \mathrm{d} z$, the temperature gradient across the sediment-water interface, is estimated as

$\frac{\mathrm{d} T}{\mathrm{~d} z} \approx \frac{T_{\mathrm{s}}-T_{\mathrm{w}}}{z_{\mathrm{sed}}}$,

where $T_{\mathrm{s}}$ is the sediment temperature, $T_{\mathrm{w}}$ is the water temperature adjacent to the sediment surface, which varies hourly and with depth, and $z_{\text {sed }}$ is the distance beneath the watersediment interface at which the sediment temperature becomes largely invariant. From data collected at four locations on Lake Mendota (Birge et al., 1927), it was found that sediment temperatures varied little at $5 \mathrm{~m}$ depth below the sediment-water interface, so $z_{\text {sed }}$ is set to be $5 \mathrm{~m}$. In addition, data from Birge et al. (1927) are used to fit a curve to describe the seasonal variation of $T_{\mathrm{s}}$

$T_{\mathrm{S}}=9.7+2.7 \sin \left[\frac{2 \pi(D-151)}{\mathrm{TD}}\right]$,

where $D$ is the number of days from the start of the year and TD is the total number of days for the year of interest (365 or 366). The vertical transfer of heat in the water column beneath the ice is regulated by an assigned thermal diffusion coefficient. The formulation is the same as that originally used in DYRESM-WQ (Hamilton and Schladow, 1997) to simulate heat transfer throughout the open water period. This 
produced diffusivities that were within the range of measurements by Ellis et al. (1991) of 1-3 times greater than molecular values.

Input for the model includes lake morphometry (lake volume and surface area as a function of elevation), initial vertical profiles for water temperature and salinity, Secchi depth, meteorological variables, and inflows/outflows. The model calculates the surface heat fluxes using meteorological variables: total daily shortwave radiation, daily cloud cover, air vapor pressure, daily average wind speed, air temperature, and precipitation. During the simulation, all parameters/coefficients in the model are kept constant. The time step in the model for calculating water temperature, water budget, and ice thickness was set to $1 \mathrm{~h}$. Snow ice compaction, and snowfall and rainfall components are updated at a daily time step, corresponding to the frequency of meteorological data input. Cloud cover, air pressure, wind speed, and air temperature are assumed to be constant throughout the day, and precipitation is assumed uniformly distributed. Shortwave radiation distribution throughout the day is computed based on the lake latitude and the day or year. The DYRESM-WQ-I model is calibrated using measured lake variables including water level, temperature profiles, ice thickness, and ice-on and iceoff dates. The overall simulation period was 104 years, starting with an isothermal (measured) water column temperature of $3.1^{\circ} \mathrm{C}$ on 7 April 1911 and ending on 31 October 2014.

\subsection{Model calibration}

The model was calibrated for the period 1995-2014 by varying the minimum layer thickness over values ranging from 0.05 to $0.5 \mathrm{~m}$ at $0.025 \mathrm{~m}$ intervals. Layer thickness values were evaluated for the least amount of deviation between predicted and observed temperature values for Lake Mendota over the period. Based on this analysis, a minimum layer thickness of $0.125 \mathrm{~m}$ was chosen as the best setting to predict water temperature at all depths. Other parameter values in the hydrodynamic and ice cover models were obtained from literature values (Table 1). To evaluate the performance of the model, root mean square error (RMSE) was used to compare simulated and observed ice cover and water temperature values for the full model period (1911-2014; see Sect. 4.2). Simulated and observed values are compared directly, with the exception of aggregation of water temperature measurements to daily intervals where subdaily intervals were available.

\subsection{Piecewise regression algorithm}

Breakpoints in the air temperature trend over the study period were determined using a piecewise linear regression (PLR) method (Tomé and Miranda, 2004; Toms and Lesperance, 2003; Ying et al., 2015) that assumes continuity in the trendlines across the breakpoint. The piecewise linear regression model finds the breakpoint, $B$, that minimizes the residual
Table 1. Values of DYRESM-ICE parameters and model simulation specifications for both hydrodynamic and ice cover portions of the model.

\begin{tabular}{|c|c|}
\hline Parameter & Value \\
\hline \multicolumn{2}{|l|}{ Hydrodynamic model parameters } \\
\hline Albedo & $0.08^{\mathrm{i}, \mathrm{ii}}$ \\
\hline Bulk aerodynamic momentum transport coefficient & $0.00139^{\mathrm{ii}}$ \\
\hline Critical wind speed $\left(\mathrm{m} \mathrm{s}^{-1}\right)$ & $4.3^{\mathrm{ii}}$ \\
\hline Effective surface area coefficient $\left(\mathrm{m}^{2}\right)$ & $1 \times 10^{7} \mathrm{iii}$ \\
\hline Emissivity of water surface & $0.96^{\mathrm{iv}}$ \\
\hline Potential energy mixing efficiency & $0.2^{\mathrm{i}, \mathrm{ii}}$ \\
\hline Shear production efficiency & $0.06^{\mathrm{i}, \mathrm{ii}, \mathrm{iii}}$ \\
\hline Vertical mixing coefficient & $200^{\mathrm{iii}}$ \\
\hline Wind stirring efficiency & $0.8^{\mathrm{ii}}$ \\
\hline Minimum layer thickness & 0.125 \\
\hline Maximum layer thickness & $0.6^{\mathrm{ii}}$ \\
\hline Vertical light attenuation coefficient & variable $^{\mathrm{V}}$ \\
\hline \multicolumn{2}{|l|}{ Ice model parameters } \\
\hline Waveband 1 , snow ice light extinction $\left(\mathrm{m}^{-1}\right)$ & $3.8^{\mathrm{vi}}$ \\
\hline Waveband 2 , snow ice light extinction $\left(\mathrm{m}^{-1}\right)$ & $20^{\mathrm{vi}, \mathrm{vii}}$ \\
\hline Waveband 1 , blue ice light extinction $\left(\mathrm{m}^{-1}\right)$ & $1.5^{\mathrm{vi}, \mathrm{vii}}$ \\
\hline Waveband 2 , blue ice light extinction $\left(\mathrm{m}^{-1}\right)$ & $20^{\mathrm{vi}, \mathrm{vii}}$ \\
\hline Waveband 1 , snow light extinction $\left(\mathrm{m}^{-1}\right)$ & $6^{\mathrm{vi}, \mathrm{vii}}$ \\
\hline Waveband 2 , snow light extinction $\left(\mathrm{m}^{-1}\right)$ & $20^{\mathrm{vi},=\mathrm{vii}}$ \\
\hline Distance of heat transfer, ice-water (m) & $0.039^{\mathrm{viii}}$ \\
\hline Density, snow ice $\left(\mathrm{kg} \mathrm{m}^{-3}\right)$ & $890^{\mathrm{vi}}$ \\
\hline Density, blue ice $\left(\mathrm{kg} \mathrm{m}^{-3}\right)$ & $917^{\mathrm{vi}, \mathrm{vii}}$ \\
\hline Density, snow $\left(\mathrm{kg} \mathrm{m}^{-3}\right)$ & variable $^{\mathrm{ix}}$ \\
\hline Compaction coefficient & variable $^{\mathrm{vi}}$ \\
\hline Thermal conductivity, snow ice $\left(\mathrm{W} \mathrm{m}-1{ }^{\circ} \mathrm{C}^{-1}\right)$ & $2.0^{\mathrm{vi}}$ \\
\hline Thermal conductivity, blue ice $\left(\mathrm{W} \mathrm{m}^{-1}{ }^{\circ} \mathrm{C}^{-1}\right)$ & $2.3^{\text {vi,vii }}$ \\
\hline Thermal conductivity, snow $\left(\mathrm{W} \mathrm{m}^{-1}{ }^{\circ} \mathrm{C}^{-1}\right)$ & variable $^{\mathrm{x}}$ \\
\hline Thermal conductivity, sediment $\left(\mathrm{W} \mathrm{m}^{-1}{ }^{\circ} \mathrm{C}^{-1}\right)$ & $1.2^{\mathrm{vi}}$ \\
\hline Thermal conductivity, water $\left(\mathrm{W} \mathrm{m}^{-1}{ }^{\circ} \mathrm{C}^{-1}\right)$ & $0.57^{\mathrm{vi}, \mathrm{vii}}$ \\
\hline
\end{tabular}

sum of squares ( $\left.\operatorname{RSS}_{\mathrm{PLR}}\right)$ of the model between the two phases (Ying et al., 2015)

$\operatorname{RSS}_{\mathrm{PLR}}=\sum_{i=1}^{n}\left[y_{i}-\alpha-k_{1} x_{i}-\left(k_{2}-k_{1}\right) \max \left(x_{i}-B, 0\right)\right]^{2}$,

where $x_{i}$ and $y_{i}$ are the time and air temperature data corresponding to the $i$ th data point, respectively, and $k_{1}$ and $k_{2}$ are the slopes of the linear fit to data before and after the breakpoint $B$. The parameter $\alpha$ is the intercept of the linear fit to data below the estimated breakpoint $B$, and $n$ is the series length.

An $F$ test was used to compare the residual sum of squares of an ordinary linear regression model with the piecewise lin- 
ear regression model with a level of $\alpha=0.05$ used to indicate significance, and the breakpoint year was determined to pass with $p=0.0016$.

\subsection{Sequential $t$ test analysis of abrupt changes}

Abrupt changes in mean annual wind speeds and lake ice cover and temperature variables were detected using the sequential $t$ test STARS (Rodionov, 2004), which can automatically detect multiple change points. A shift occurs when a statistically significant difference exists between the mean value of the variable before and after a certain point based on the $t$ test. The variables were tested using a threshold significance level $p=0.05$, a Huber weight parameter, $h=1$ (North et al., 2013; Rodionov, 2006), and a cut-off length $L=15$ years (North et al., 2013).

\section{Model input data}

\subsection{Bathymetry}

Lake Mendota $\left(43^{\circ} 40^{\prime} \mathrm{N}, 89^{\circ} 24^{\prime} \mathrm{W}\right)$ has a surface area of $39.4 \mathrm{~km}^{2}$ and maximum fetch of $9.8 \mathrm{~km}$ (Kitchell, 1992). The mean depth is $12.7 \mathrm{~m}$, and maximum depth is $25.3 \mathrm{~m}$. For detailed bathymetry refer to Kamarainen et al. (2009).

\subsection{Meteorological variables}

Daily meteorological data required to run the DYRESMWQ-I model include solar radiation, air temperature, vapor pressure, wind speed, cloud cover, rainfall, and snowfall. Daily air temperatures are computed as the average of daily maximum and minimum temperatures. Vapor pressure, wind speed, and cloud cover are also entered as daily average values while solar radiation, rainfall, and snowfall are daily accumulation values.

Meteorological data for the Madison area have been continuously recorded since 1869 , however, the station and techniques have changed several times. Robertson (1989) constructed a continuous, homogeneous daily meteorological data set from 1884 to 1988 by adjusting for changes in site location and observation time, and resultant changes in the surface roughness (e.g., height of surrounding trees and buildings). These data were appended with data from the most recent weather station of the National Climate Data Center (NCDC, NOAA) located in Madison (MSN) Dane County Regional Airport (Truax Field), approximately $4.5 \mathrm{~km}$ east from the simulation location, the same site as that used in 1988. All data except solar radiation can be obtained for MSN from http://www.ncdc.noaa.gov/, except solar radiation which can be obtained from http://www.sws. uiuc.edu/warm/weather/ (approximately $150 \mathrm{~km}$ southeast of Lake Mendota). Since Robertson (1989) adjusted all historical data to that collected in 1988, no adjustments are applied to the recent data except for wind. In 1996, a discon- tinuity in the wind record was caused by change in observational techniques and sensor locations (McKee et al., 2000). To address the nonclimatic changes in wind speed, data from MSN are carefully compared with those collected from the tower of the Atmospheric and Oceanic Science Building at the University of Wisconsin-Madison (http://ginsea. aos.wisc.edu/labs/mendota/index.htm), approximately $4 \mathrm{~km}$ south of simulation location. Hourly data from both sites ( $U_{\text {MSN,hourly }}$ and $U_{\text {AOS,hourly }}$ ) during 2003-2010 were used to form a $4 \times 12$ (four components of wind direction $\times 12$ months) matrix $\left(K_{4,12}\right)$ of wind correction factors, yielding $U_{\mathrm{AOS} \text {,daily }}=K_{i, j} \times U_{\mathrm{MSN} \text {,daily. }}$ A comparison of results indicated that the MSN weather station measured a higher magnitude in winds out of the east by $5 \%$ and lower magnitude in winds out of the west and south by 30 and $10 \%$, respectively. The adjusted wind data $\left(=K_{i, j} \times U_{\mathrm{MSN} \text {,daily }}\right)$ are used in the model simulation. Overall the adjusted wind data show a decline in mean wind velocities of $16 \%$ from 1988-1993 to 1994-2014) compared to 7\% at a nearby weather station with no known observational changes (St. Charles, Illinois; $150 \mathrm{~km}$ southeast of Lake Mendota).

\subsection{Light extinction}

Seasonal Secchi depths can be used to determine the light extinction coefficient for DYRESM-WQ-I. Lathrop et al. (1996) compiled Secchi depth data for Lake Mendota between 1900 and 1993 (1701 daily Secchi depth readings from 70 calendar years), and summarized the data for 6 seasonal periods: winter (ice-on to ice-off date), spring turnover (ice-off date to 10 May), early stratification (11 May to 29 June), summer (30 June to 2 September), destratification (3 September to 12 October), and fall turnover (13 October to ice-on date). After 1993, Secchi depths were obtained from the North Temperate Lakes - Long Term Ecological Research (NTL-LTER) (https://portal.lternet.edu/nis/home. jsp\#). For years with no Secchi data, the long-term mean seasonal Secchi depth was used to estimate light extinction. Light extinction coefficients are calculated as a function of Secchi depth using the equation, $k=1.1 / z_{\mathrm{s}}^{0.73}$ (Williams et al., 1980), where $k$ is the light extinction coefficient and $z_{\mathrm{s}}$ is the measured Secchi depth, in meters.

\subsection{River inflow and outflow}

Daily inflow measurements have been made on selected Lake Mendota tributaries since 1974, and daily outflow from the lake has been measured since 1975. Streamflow for the tributaries were obtained from http://waterdata.usgs.gov/wi/nwis/ sw/. Daily outflow from 1975 to 1997 were calculated from gate/lock/bypass pipe USGS ratings and local governmental daily operational records. Daily outflow from 1998 to 2003 were estimated from monthly outflow estimates from downstream Lake Waubesa and Mendota outlet data from earlier years. Daily outflow from 2003 to the present, were ob- 
tained from http://waterdata.usgs.gov/wi/nwis/uv/?site_no= 05428000. These measurements were used to calculate total daily inflow and outflow. Total daily inflow and outflow from 1930 to 1974 were estimated from measurements made at the gauging station downstream of the lake using the drainage-area ratio method (Maidment, 1993). Prior to 1930 , total inflow and outflow were calculated using a water budget approach, i.e., the balance of inflow/outflow, precipitation, evaporation, and lake level changes. The inflow/outflow is the residual unknown term of the water balance where other terms include evaporation, rainfall, and water level. The calculation is performed at the interval of water level measurements and the residual term is then distributed evenly across the number of days between water level measurements. Water level of Lake Mendota has been recorded since 1916 at the Yahara River inlet in the north of the lake (http://waterdata.usgs.gov/wi/nwis/dv). Prior to 1916 , the long-term mean lake level was assumed in water budget calculations. River water temperature has been recorded at the Yahara River inlet since 2002 (US Geological Survey, http://waterdata.usgs.gov/nwis). To estimate daily river temperatures prior to 2002, river temperatures were estimated from air temperatures (Hsieh, 2012). A linear regression was used to correlate river temperatures and weekly average air temperature data during 2002-2009 for air temperatures above the freezing temperature $\left(r^{2}=0.86\right)$, and a separate polynomial regression analysis was performed for air temperatures below the freezing temperature $\left(r^{2}=0.68\right)$.

\subsection{Lake ice cover and water temperature}

Observed ice cover data from 1911-2014 (available at NTL-LTER website: https://portal.lternet.edu/nis/home. jsp\#), showed that Lake Mendota, on average, freezes on 22 December (ice-on date), breaks up on 31 March (iceoff date), and has an ice duration of 98 days. Ice thickness and snow depth during the study period were compiled from various sources: 1911-1916 (unpublished data from E. Birge, University of Wisconsin); daily ice thickness during 1961-1962, 1962-1963, and for part of the winter 1963-1964 (Stewart, 1965); 1975-1995 (unpublished data, D. Lathrop, Wisconsin Department of Natural Resources); after 1995, ice thickness and snow depth were sampled once or twice every winter by the NTL-LTER Program (https: //portal.lternet.edu/nis/home.jsp\#). In addition, during winters of 2008-2009 and 2009-2010, blue ice, snow ice, total ice (blue ice + snow ice), and snow cover depth were measured weekly at multiple locations on the lake (Hsieh, 2012). In total, there are 251 measurements of total ice, 21 for blue ice, 21 for snow ice, and 49 for snow depth during 1911 to 2014.

Long-term water temperature records were obtained from Robertson (1989) and the NTL-LTER data set (https://portal. lternet.edu/nis/home.jsp\#). The frequency of water temperature data varied widely from only one or two profiles per year
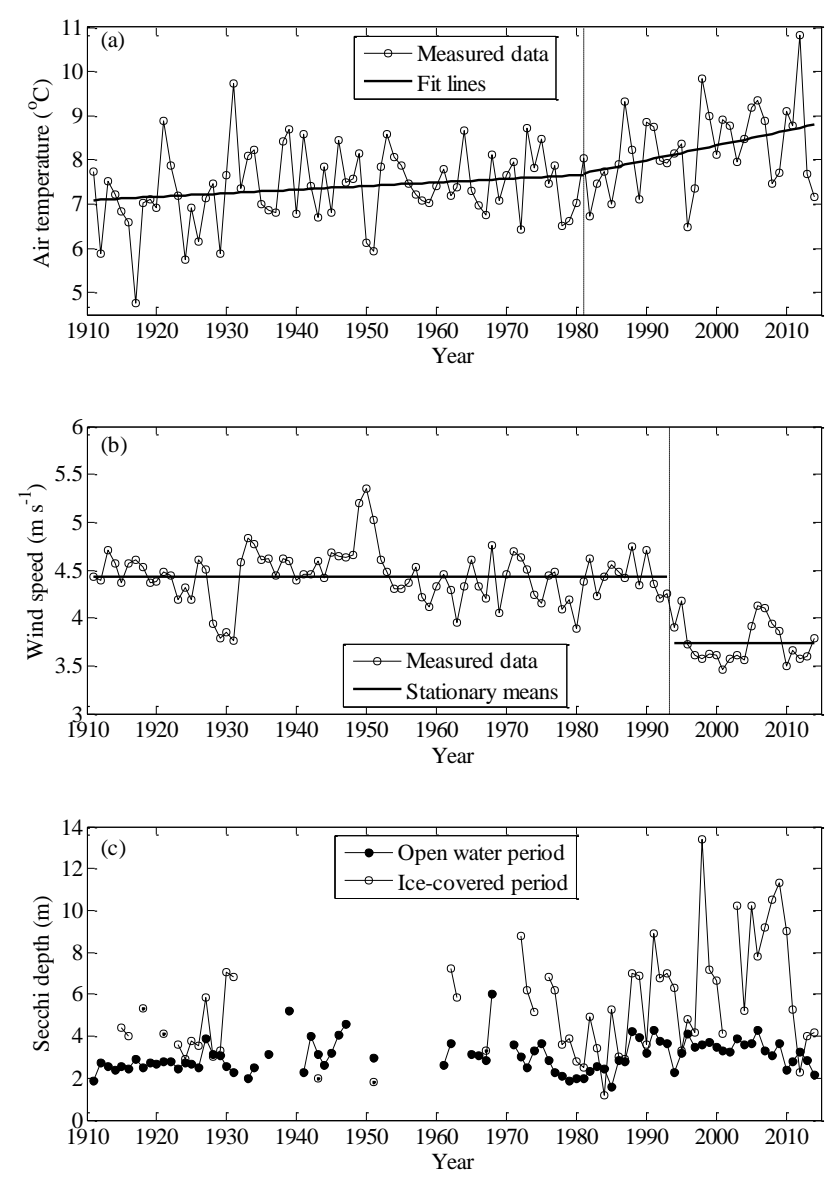

Figure 1. Historical record of annual average (a) air temperature and (b) wind speed in Madison, WI, USA, and (c) Secchi depth in Lake Mendota.

to several profiles for a given day, while there were no data collected in some years between 1931 and 1970. The vertical resolution of the water profiles varied from 0.5 to $2 \mathrm{~m}$ and sometimes $5 \mathrm{~m}$ when the water column was weakly stratified.

\section{Results}

\subsection{Shifts in air temperature, wind speed, and water clarity}

Annual air temperature (Fig. 1a) had a relatively small increase from 1910 until 1980, but has increased dramatically since 1981. Based on a piecewise linear regression algorithm, there was a small warming trend of $0.081{ }^{\circ} \mathrm{C}$ per decade during 1911-1980, followed by a dramatic change (a warming trend of $334^{\circ} \mathrm{C}$ per decade) from 1981-2014. Figure $1 \mathrm{~b}$ shows that mean annual wind speed was $4.44 \mathrm{~m} \mathrm{~s}^{-1}$ until 1994, when a significant shift occurred to $3.74 \mathrm{~m} \mathrm{~s}^{-1}(15 \%$ reduction) based on the sequential $t$ test STARS method (Rodionov, 2004). Figure 1c shows Secchi depth for Lake Men- 
dota; however, no statistical trend was obtained due to the incompleteness of the data.

Combining the statistically significant breakpoint in air temperature trend that occurred in 1981 and the shift in wind speed in 1994, the Madison climate may be broken into three different periods. The first, from 1911-1980, was a relatively cool period and had an average wind speed of $4.44 \mathrm{~m} \mathrm{~s}^{-1}$. The second period (1981-1993) occurred after the breakpoint in the air temperature trend and had a warmer air temperature and a wind speed of $4.44 \mathrm{~m} \mathrm{~s}^{-1}$. The third period (1994-2014) occurred after the shift in wind speed from 4.44 to $3.74 \mathrm{~m} \mathrm{~s}^{-1}$ and had even warmer air temperatures.

\subsection{Model validation and long-term simulations}

Here, we provide results of model validity comparisons followed by results of long-term changes in both observed (where available) and simulated conditions for snow and ice thickness, ice-on and ice-off dates, lake water temperature, summer stratification, and thermocline depth.

\subsubsection{Ice and snow thickness}

Figure 2 shows the comparison of the long-term (from 1911 to 2014) simulation and measured data for blue ice, white ice, and total ice thickness and snow depth. Mean absolute differences between simulated and measured thickness of total ice, blue ice, snow ice, and snow cover are $7.8 \mathrm{~cm}(n=251$; $\mathrm{RMSE}=7.9 \mathrm{~cm}), 5.5 \mathrm{~cm}(n=21 ; \mathrm{RMSE}=3.3 \mathrm{~cm}), 1.9 \mathrm{~cm}$ $(n=21 ; \mathrm{RMSE}=2.3 \mathrm{~cm}), 4.1 \mathrm{~cm}(n=49 ; \mathrm{RMSE}=3.7 \mathrm{~cm})$, respectively. Some discrepancy between the model results and measurements may be due to the 1-D structure of the model. The DYRESM-WQ-I model provides only the lakewide average ice and snow depths, hence no horizontal variation. For a medium-to-large lake, such as Lake Mendota, spatial variations in ice and snow depths should be expected (Bengtsson, 1986). In the winters of 2008-2009 and 2009-2010, ice measurements were made at multiple locations on Lake Mendota (Hsieh, 2012). Data in 2008-2009 showed variations in ice thickness. Total ice thickness in the middle of the lake was approximately $12 \mathrm{~cm}$ greater than that at a littoral location (water depth $=2 \mathrm{~m}$ ) in late winter. In 2009-2010, ice cover was fairly spatially uniform through the entire sampling period. Consequently, discrepancy between model results and measurements is expected in those years when ice thickness varied spatially. The accuracy of predictions from DYRESM-WQ-I was compared with other models: MINLAKE (Fang and Stefan, 1996b) produced standard errors of $11 \mathrm{~cm}$ for total ice thickness and $6 \mathrm{~cm}$ for snow cover for Thrush Lake, Minnesota, and $12 \mathrm{~cm}$ for total ice and $7 \mathrm{~cm}$ for snow cover for the north basin of Little Rock Lake, Wisconsin. In comparison, similar discrepancies between modeled and observed ice thickness and snow cover were produced from other models including LIMNOS (Vavrus et al., 1996) on Lake Mendota, Wisconsin with dis-

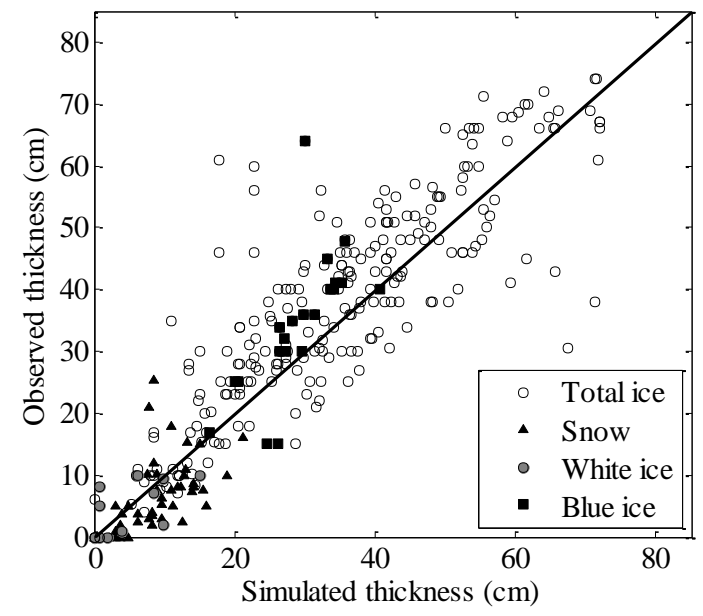

Figure 2. Comparison between observations and simulated total ice, snow cover, white ice, and blue ice.

crepancies of 4-9 cm for ice cover; MLI (Rogers et al., 1995) on Harmon Lake, British Columbia, which had up to $6 \mathrm{~cm}$ error for ice cover and $4 \mathrm{~cm}$ error for snow cover; and CLIMo (Duguay et al., 2003) on lakes in Barrow, Alaska (differences of 5-6 cm for ice thickness); Poker Flat, Alaska (mean absolute error of $2 \mathrm{~cm}$ for ice cover and underestimation of snowice thickness of $7 \mathrm{~cm}$ ); and Churchill, Manitoba (ice thickness observations were within model values for the snow-free and $100 \%$ snow-covered scenarios). Duguay et al. (2003) found that variability in snow density and snow accumulation play a significant role in ice thickness, which may account for discrepancies between simulated and observed ice cover thicknesses in our study. In general, DYRESM-WQ-I predicts the ice and snow depths fairly accurately. Figure $3 \mathrm{a}$ shows the evolution of simulated ice and snow thickness with multiple ice and snow thickness measurements taken during the winter of 2009-2010. Once ice develops, water beneath the ice continues to freeze, adding to the ice thickness, as heat is conducted from water to the air. In this winter period, lake ice grew fast initially and then slowed substantially. Eventually, the ice reaches its maximum thickness and stops growing (Ashton, 1986). Once air temperatures begin to warm up, ice quickly thins until the ice-off date. Overall, the model is able to capture the growing ice cover as well as the temporally variable snow cover found on the lake.

Figure 3b shows the long-term (1911-2014) simulated annual maximum ice thickness during each winter. The annual maximum thickness varied widely from $20.1 \mathrm{~cm}$ (1997$1998)$ to $72.0 \mathrm{~cm}$ (1911-1912) during the 1911-2014 period. The timing when ice reached its maximum thickness also varied considerably, from 17 January (1973) to 7 April (1923). In 73 out of 103 winters, ice reached its maximum thickness in March. Linear regression analysis on simulated annual maximum ice thicknesses indicates that it has decreased at a rate of $12.7 \mathrm{~cm}$ per century during $1911-$ 
Table 2. Mean values of climate drivers and lake variables of three hypothesized periods during 1911-2014.

\begin{tabular}{|c|c|c|c|c|c|c|c|}
\hline \multirow[t]{2}{*}{ Driver/variable } & \multirow[t]{2}{*}{ Unit } & \multicolumn{3}{|c|}{ Period } & \multicolumn{3}{|c|}{ Difference in mean } \\
\hline & & $\begin{array}{l}\text { (1) } 1911- \\
1980\end{array}$ & $\begin{array}{l}\text { (2) 1981- } \\
1993\end{array}$ & $\begin{array}{l}\text { (3) } 1994- \\
2014\end{array}$ & $\begin{array}{l}\text { (1) and } \\
\text { (2) }\end{array}$ & $\begin{array}{l}\text { (2) and } \\
\text { (3) }\end{array}$ & $\begin{array}{l}\text { (1) and } \\
\text { (3) }\end{array}$ \\
\hline \multicolumn{8}{|l|}{ Lake driver } \\
\hline Air temperature (slope) & ${ }^{\circ} \mathrm{C}$ decade ${ }^{-1}$ & 0.081 & 0.334 & 0.334 & & & \\
\hline Wind speed & $\mathrm{m} \mathrm{s}^{-1}$ & 4.44 & 4.44 & 3.74 & & & \\
\hline \multicolumn{8}{|l|}{ Lake variables } \\
\hline Maximum ice thickness & $\mathrm{cm}$ & 49.8 & 44.9 & 40.7 & -4.9 & -4.2 & $-9.1^{*}$ \\
\hline Ice-on date (model) & Date & $21 \mathrm{Dec}$ & $23 \mathrm{Dec}$ & $29 \mathrm{Dec}$ & 2 days & 6 days & 8 days* \\
\hline (observation) & Date & $21 \mathrm{Dec}$ & $24 \mathrm{Dec}$ & $29 \mathrm{Dec}$ & 3 days & 5 days & 8 days* \\
\hline Ice-off date (model) & Date & 9 Apr & $2 \mathrm{Apr}$ & $30 \mathrm{Mar}$ & -7 days & -3 days & -10 days* \\
\hline (observation) & Date & $3 \mathrm{Apr}$ & $27 \mathrm{Mar}$ & $26 \mathrm{Mar}$ & -7 days & -1 days & -8 days $*$ \\
\hline Ice duration (model) & Days & 108.7 & 99.5 & 91.1 & $-9.2^{*}$ & $-8.4^{*}$ & $-17.6^{*}$ \\
\hline (observation) & Days & 103.2 & 92.9 & 85.6 & $-10.3^{*}$ & $-7.3^{*}$ & $-17.6^{*}$ \\
\hline Under-ice water temperature & ${ }^{\circ} \mathrm{C}$ & 1.74 & 1.81 & 2.08 & 0.07 & 0.27 & $0.34^{*}$ \\
\hline Freeze-over water temperature & ${ }^{\circ} \mathrm{C}$ & 1.03 & 1.14 & 1.66 & 0.11 & 0.52 & $0.63^{*}$ \\
\hline Stratification onset date & Date & 24 May & 17 May & 18 May & -7 days & -1 days & -6 days \\
\hline Midsummer epilimnetic temperature & ${ }^{\circ} \mathrm{C}$ & 23.0 & 23.2 & 23.4 & 0.2 & 0.2 & 0.4 \\
\hline Midsummer hypolimnetic temperature & ${ }^{\circ} \mathrm{C}$ & 12.0 & 11.8 & 10.9 & -0.2 & $-0.9^{*}$ & $-1.1^{*}$ \\
\hline Epilimnion-hypolimnion temp. difference & ${ }^{\circ} \mathrm{C}$ & 10.9 & 11.4 & 12.5 & 0.5 & 1.1 & $1.6^{*}$ \\
\hline Hypolimnetic heating (1 July-31 August) & ${ }^{\circ} \mathrm{C}$ & 0.699 & 0.688 & 0.583 & -0.011 & -0.105 & -0.116 \\
\hline Turnover date & Date & 20 Sept & $21 \mathrm{Sept}$ & 3 Oct & 1 day & 12 days* & 13 days* \\
\hline Stratification duration & Days & 119.4 & 127.4 & 138.6 & 8.0 & 11.2 & $19.2^{*}$ \\
\hline
\end{tabular}

Asterisks $(*)$ mark significant differences between two period $(p<0.05)$.
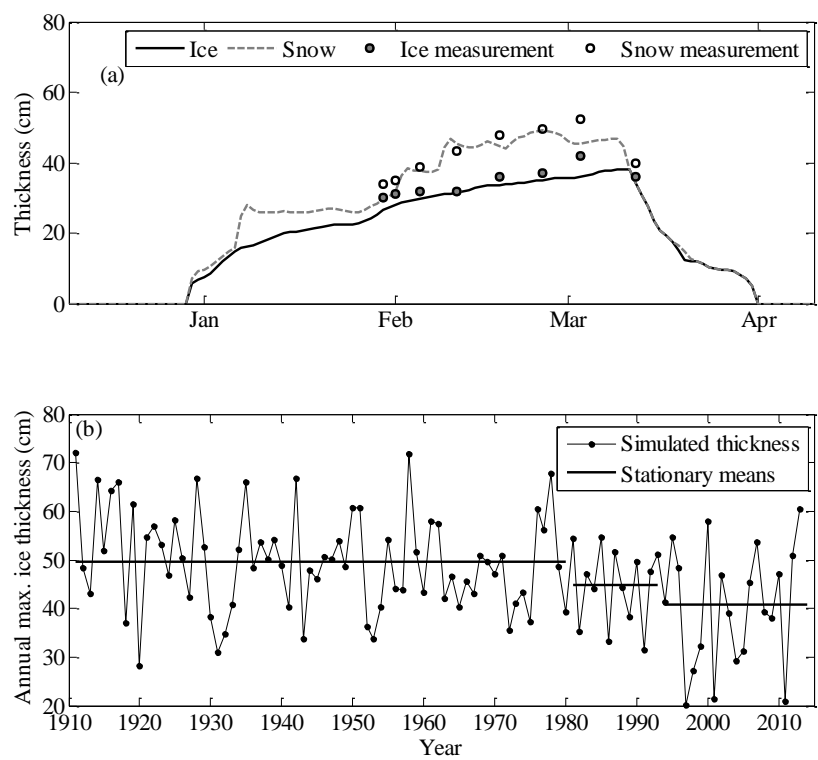

Figure 3. (a) Simulated ice and snow with measured values for the winter 2009-2010 and (b) simulated annual maximum total ice thickness.
2014. These results are much smaller than those for European lakes of similar latitudes (Choiński et al., 2010, 2013; Marszelewski and Skowron, 2006; Skowron, 2009), with changes ranges from 0.20 to $0.60 \mathrm{~cm} \mathrm{yr}^{-1}$, almost double that of Lake Mendota if the current change per year is extended to change per century. A $t$ test of the mean values shows a statistically significant $(p<0.05)$ difference in the mean annual maximum ice thickness between period 1 (1911-1980) and period 3 (1994-2014). Period 2 was not statistically different from either of the other two periods (Table 2).

\subsubsection{Ice-on and ice-off dates}

Figure 4 shows measured and simulated ice-on date, iceoff date, and ice duration on the lake. The measured iceon date is defined as the first day when the lake becomes fully covered in ice, and the ice-off date is the last day of the ice breakup before the open water season. Simulated results and observations are in good agreement, with a mean absolute difference of 2.3 days (RMSE $=2.4$ days) for iceon date and 5.7 days (RMSE $=4.8$ days) for ice-off date. It is noted that both the mean error and RMSE are much smaller than the interannual variability in the observed ice-on dates (standard deviation $(\mathrm{SD})=11.2$ days) and ice-off dates ( $\mathrm{SD}=10.6$ days). Interannual variations in ice cover on Lake Mendota were large in the past century. Observed ice-on 
dates ranged from 3 December (1929) to 30 January (1931) with a range of 58 days. Ice-off dates ranged from 27 February (1998) to 20 April (1923) with a range of 51 days. The model successfully captures the interannual variations of iceon and ice-off dates. For example, it reproduces the unusual late ice-on date in 1930-1931 and several noticeable early ice breakups associated with intense El Niño-Southern Oscillation (ENSO) events, i.e., 1965, 1972, 1982, and 1997 (Anderson et al., 1996; Magnuson et al., 2000; Robertson et al., 2002). Figure $4 \mathrm{~b}$ shows the ice duration, defined as the period between ice-on and ice-off dates. The mean absolute difference in ice duration between the model results and observations is 6.6 days ( $\mathrm{RMSE}=6.1$ days), compared to the observed SD of 17.9 days. Overall, we consider the model performs well in simulating ice-on and ice-off dates and ice cover duration.

Long-term trends in ice formation are examined by applying linear regression to the model results and observed data. Figure 4 clearly shows progressively later freezing, earlier breakup, and shorter duration in Lake Mendota from 1911 to 2014. Based on model results, ice-on dates exhibit a trend toward later dates by 9.0 days per century, ice-off dates exhibit a trend toward earlier dates of 12.3 days per century, and ice duration exhibits a trend of shorter duration by 21.3 days per century. Model results are in good agreement with those obtained from the observed data (7.4 days later ice-on dates, 9.3 days earlier for ice-off dates, and 18.0 days shorter duration per century). All linear trends from the observed and simulated data are statistically significant $(p<0.05)$. Similar tendencies have been observed at other lakes, which show decreasing ice cover duration from later ice-on dates and earlier ice-off dates (Choiński et al., 2010, 2013; Marszelewski and Skowron, 2006; Skowron, 2009). However, lakes in near the Great Lakes, North America, and Poland have shown larger rates of change over periods of less than a century. For example, Jensen et al. (2007) observed average ice duration decreases of 5.3 days decade ${ }^{-1}$ from 1975-2004 in the Great Lakes region, and Polish lakes had observed changes as large as 0.8 to 0.9 days $\mathrm{yr}^{-1}$ for the period 1961-2000 (Marszelewski and Skowron, 2006) and 0.5 to 0.6 days $\mathrm{yr}^{-1}$ from 1956-2005 (Skowron, 2009). Mean values of ice-on date, ice-off date, and ice duration for the three selected periods, i.e., 1911-1980, 1981-1993, and 1994-2010, (see Table 2 and Fig. 4) show a statistically significant ( $p<0.05$, based on $t$ test) difference between period 1 (1911-1980) and period 3 (1994-2014) for all ice cover variables and a statistically significant $(p<0.05)$ difference between period 1 and period 2 (1981-1993) for ice cover duration.

\subsubsection{Water temperature}

The performance of the model in simulating water temperatures in the lake is presented in Figs. 5 and 6. For temperatures at the near-surface water, we use the simulated volumeweighted mean water temperatures between depths of 0 and
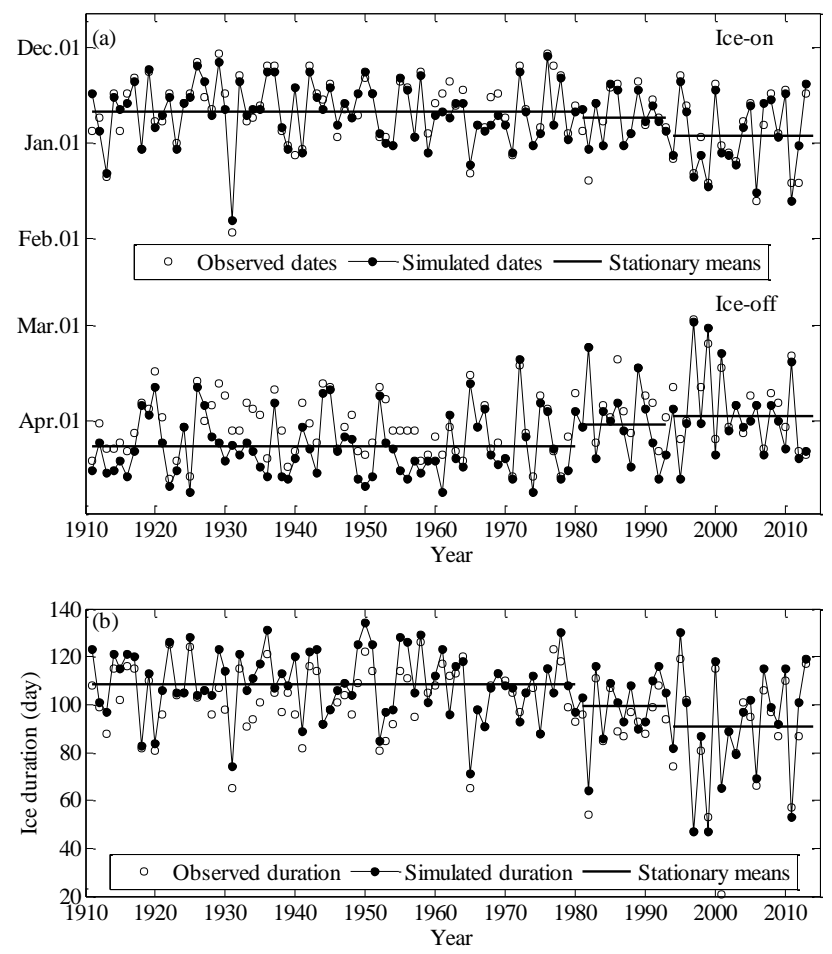

Figure 4. Observed and simulated (a) ice-on and ice-off dates and (b) ice cover duration. The annual ice cover was plotted in the first year of the winter, e.g., the winter 1911-1912 was plotted in the year 1911. Stationary means for three selected periods are denoted by solid lines.

$10 \mathrm{~m}$. The simulated epilimnetic temperatures compare well with those estimated from the measured data; the annual mean absolute error is $0.69{ }^{\circ} \mathrm{C}\left(n=3239\right.$; $\left.\mathrm{RMSE}=0.30{ }^{\circ} \mathrm{C}\right)$, demonstrating the ability of the model to simulate the heat budget in the upper mixed layer of the lake. Near-surface temperatures range from about $0{ }^{\circ} \mathrm{C}$ in winter to $26.1^{\circ} \mathrm{C}$ in summer, and strongly respond to the net surface heat flux, as illustrated by the $2-3^{\circ} \mathrm{C}$ variations that occur in both simulated and measured data, e.g., in the summer of 1921 , 1960, 1994, and 2009 (Fig. 5). Overall the model captures interannual variations in epilimnetic temperatures even during extreme years; for example, the relatively high maximum epilimnetic temperatures $\left(>25^{\circ} \mathrm{C}\right)$ in the summers of 1949 , $1955,1963,1987,1988$, and 1999 , and relatively cold annual maximum epilimnetic temperatures $\left(\sim 22^{\circ} \mathrm{C}\right)$ in the summers of 1915, 1924, and 1942.

Figure 6 shows the comparison between the simulated volume-weighted near-bottom (within the hypolimnion) temperatures over the depths between $20-25 \mathrm{~m}$ and those estimated from the measured data. The mean absolute error is $1.04{ }^{\circ} \mathrm{C}\left(n=3239\right.$; $\left.\mathrm{RMSE}=0.53{ }^{\circ} \mathrm{C}\right)$. Near-bottom temperatures range from $0.2^{\circ} \mathrm{C}$ in winter to $19.1^{\circ} \mathrm{C}$ in autumn, which is approximately $10^{\circ} \mathrm{C}$ less than the variation in nearsurface temperatures. Near-bottom temperatures are lowest 

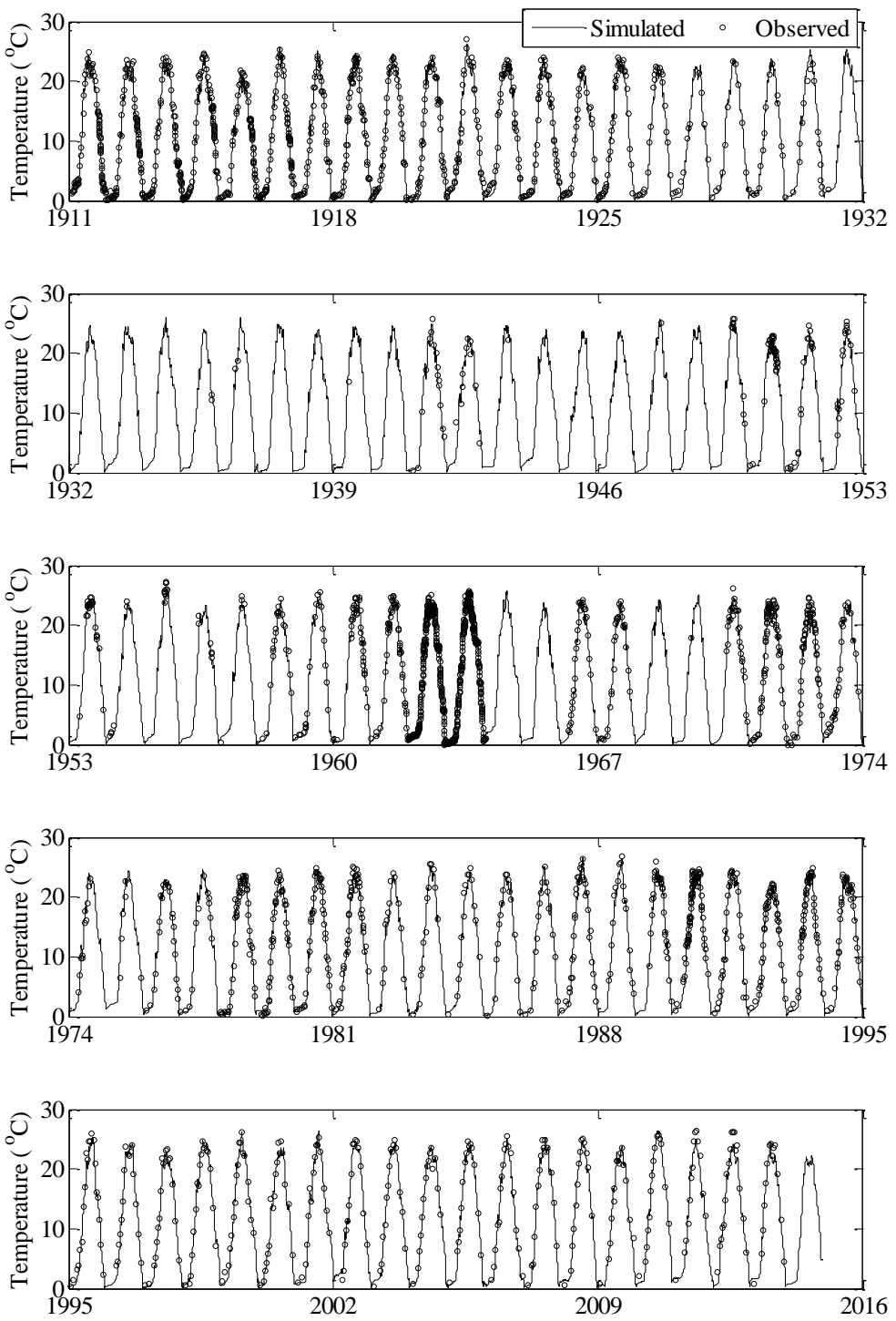

Figure 5. Time series of the simulated and observed volume-weighted near-surface (epilimnetic) temperature (0-10 m) from 1911-2014.

when the lake first freezes, and then slowly increase because of heat released from the bottom sediment. However, we cannot discount that cold inflows could also penetrate into the lake and affect temperature at the selected depths $(20-25 \mathrm{~m})$. After ice breakup and just prior to seasonal stratification, temperature in near-bottom waters is usually identical to surface waters and the whole water column undergoes a period of sustained increase in temperature. Hypolimnetic temperatures then stay relatively constant during the stratified period with limited heat exchange associated with strong temperature gradients across the thermocline.

To further examine the model's capability of simulating the extreme differences in temperature, we compare measured and modeled temperatures under years with cold (1924) and warm (1963) epilimnion temperatures and cold (1972) and warm (1926) hypolimnion temperatures.
Figure 7 shows that the model accurately captures the extreme conditions in those 4 years. For plotting, measurement values are assumed to remain constant for the duration of time between measurements. Measurements are generally taken at $1 \mathrm{~m}$ intervals over the depth of the water column, but in instances with irregular measurement intervals, temperatures are interpolated at intervals of $1 \mathrm{~m}$ for the depth of the lake. Slight variation in temperatures at each depth may be attributed to differences between the averaged seasonal Secchi depth values used to drive the model and the observed Secchi depth values. To demonstrate the model's ability to simulate changes in ice conditions and water temperature under the ice, measured and simulated conditions for these extreme years are presented in Fig. 8. In this figure, the time frame and temperature scales are adjusted to highlight the subtle changes in winter and ice conditions and 

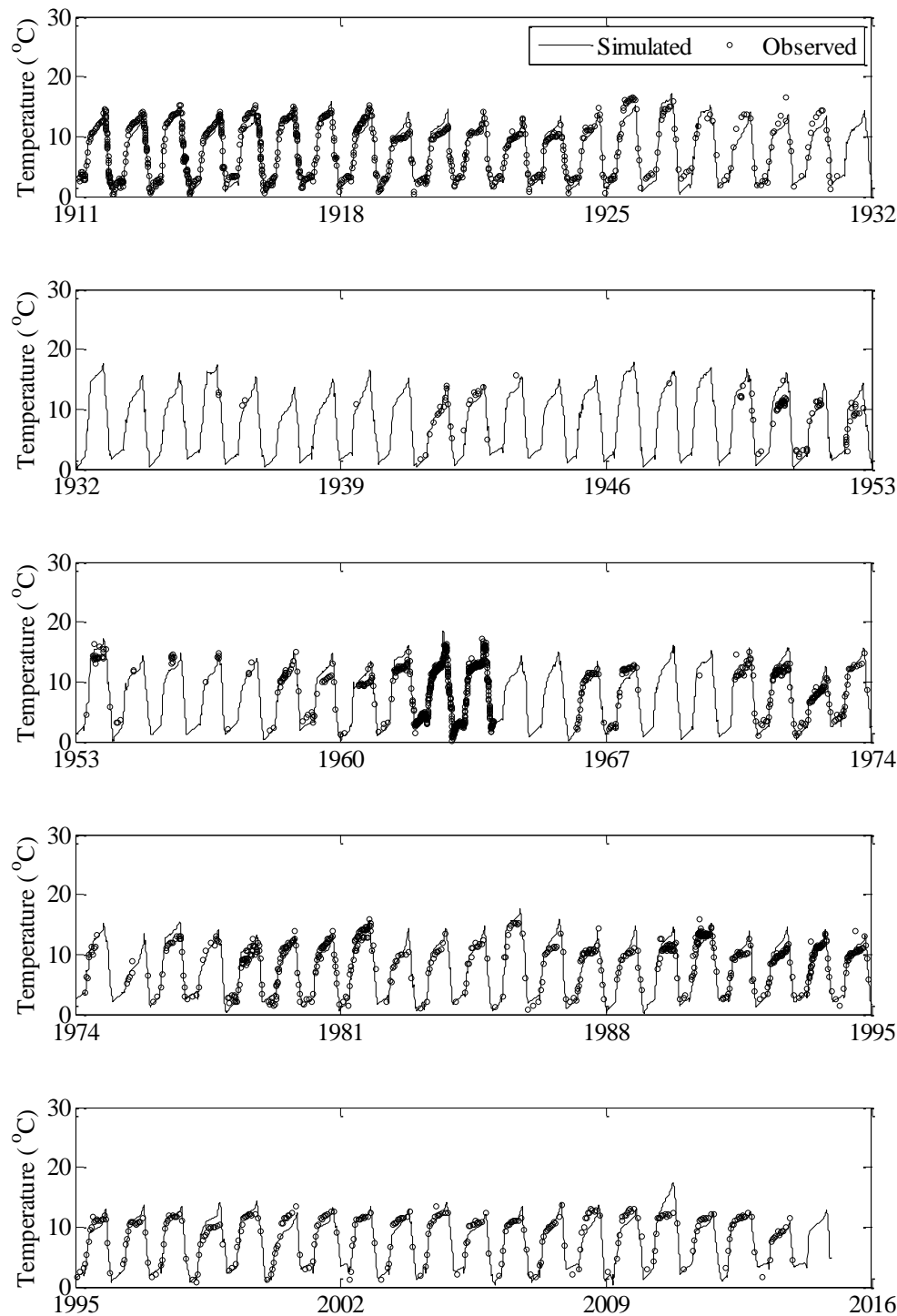

Figure 6. Time series of the simulated and observed volume-weighted near-bottom (hypolimnetic) temperatures (20-25 m) from 1911-2014.

modeled ice and snow thickness are added to the top of the plots. While some discrepancies in temperature are recognized in the model comparison, the model generally captures the inverse stratification under the ice cover. Updated measurements of sediment temperature during winter may provide a better estimate of the sediment heat flux during ice cover conditions, and improve under-ice temperature predictions. Overall, the model can reliably simulate water temperature in open water and ice seasons for extreme cold and warm years.

Midsummer (averaged between 16 July and 15 August when the thermocline was well established) epilimnetic ( 0 $10 \mathrm{~m}$ ) and hypolimnetic (20-25 m) simulated temperatures from 1911 to 2014 are shown in Fig. 9a. Epilimnetic temperatures range from 19.7 to $24.8^{\circ} \mathrm{C}$. There is no statistically significant temporal trend in the midsummer epilim- netic temperatures, which may be partly explained by the lack of a warming trend for the midsummer air temperature in the Madison area based on the measured meteorological data (Kucharik et al., 2010). In contrast, hypolimnetic temperatures range from 7.8 to $16.2^{\circ} \mathrm{C}$. The interannual variation in hypolimnetic temperatures $\left(\mathrm{SD}=1.74^{\circ} \mathrm{C}\right)$ is greater than that in epilimnetic temperatures $\left(\mathrm{SD}=1.0^{\circ} \mathrm{C}\right)$. Simulated hypolimnetic temperatures show a decreasing trend of $-1.4^{\circ} \mathrm{C}$ per century $(p<0.05)$. Figure $9 \mathrm{~b}$ shows that the decreased hypolimnetic temperatures resulted in the epilimnion-hypolimnion temperature difference increasing by $2.0^{\circ} \mathrm{C}$ per century $(p<0.05)$. Midsummer hypolimnetic temperature and epilimnion $(0-10 \mathrm{~m})$-hypolimnion (20-25 m) temperature difference both exhibit significant $(p<0.05)$ mean differences between period 1 (1911-1980) and period 3 (1994-2014), as shown in Table 2. 

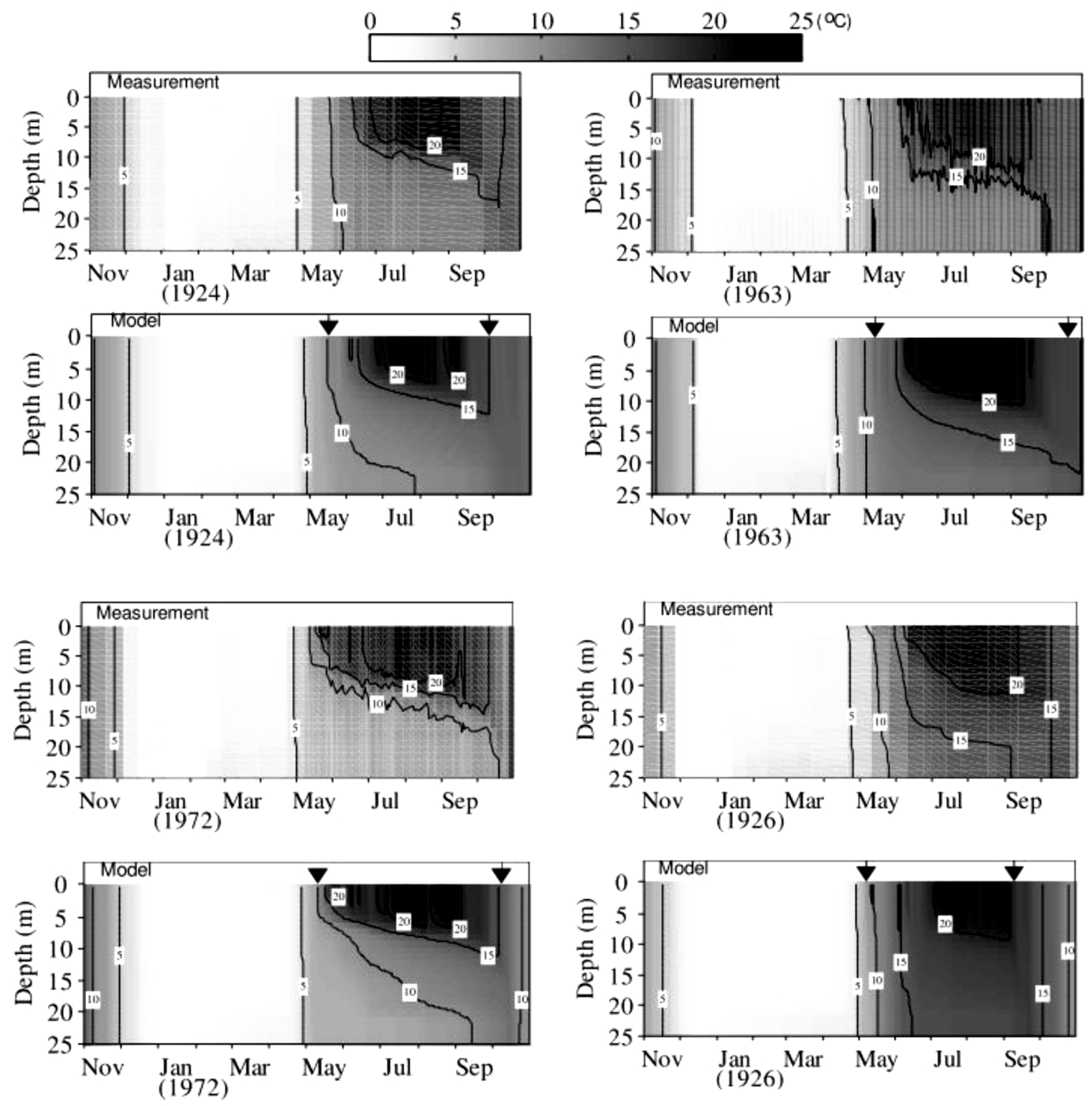

Figure 7. Comparison between the measured and simulated water temperatures as a function of time and depth under the cold epilimnetic year (1924), warm epilimnetic year (1963), cold hypolimnetic year (1972), and warm hypolimnetic year (1926) in Lake Mendota. Arrows mark the dates of onset of stratification and fall turnover.

Figure 10 shows the simulated long-term (104-year) mean under-ice water temperature (volume-weighted average of all depths) ranging from 0.78 to $3.07^{\circ} \mathrm{C}$ (mean $=1.74^{\circ} \mathrm{C}$; $\left.\mathrm{SD}=0.54^{\circ} \mathrm{C}\right)$. Based on model results, under-ice temperatures reveal a significant increasing trend $(p<0.05)$ of $0.48^{\circ} \mathrm{C}$ per century during $1911-2014$, suggesting that air temperature and wind speed may affect under-ice water temperature. For the selected periods, the under-ice (bold lines) and freeze-over (dashed lines; volume-weighted average of all depths) water temperatures exhibit interesting features. The difference between the water temperature over the entire ice-covered period and the freeze-over water temperature has decreased through time, indicating less heat gain during the winter, which may relate to a shorter time to transfer heat and a smaller gradient in temperatures between the lake and the bottom sediments. The under-water ice temperatures and freeze-over water temperatures both show significant $(p<0.05)$ differences between period 1 (1911-1981) and period 3 (1994-2014), as shown in Table 2.

\subsubsection{Summer stratification period and thermocline depth}

We characterize summer stratification by the dates of the onset of stratification and fall turnover, and the total duration of stratification. Accurately describing these conditions requires high frequency observations, which is challenging for long-term data sets. As a result, we used modeled data to determine these variables. The dates of stratification onset/fall turnover are defined as the day when the surfaceto-bottom temperature difference is greater/less than $2^{\circ} \mathrm{C}$ 

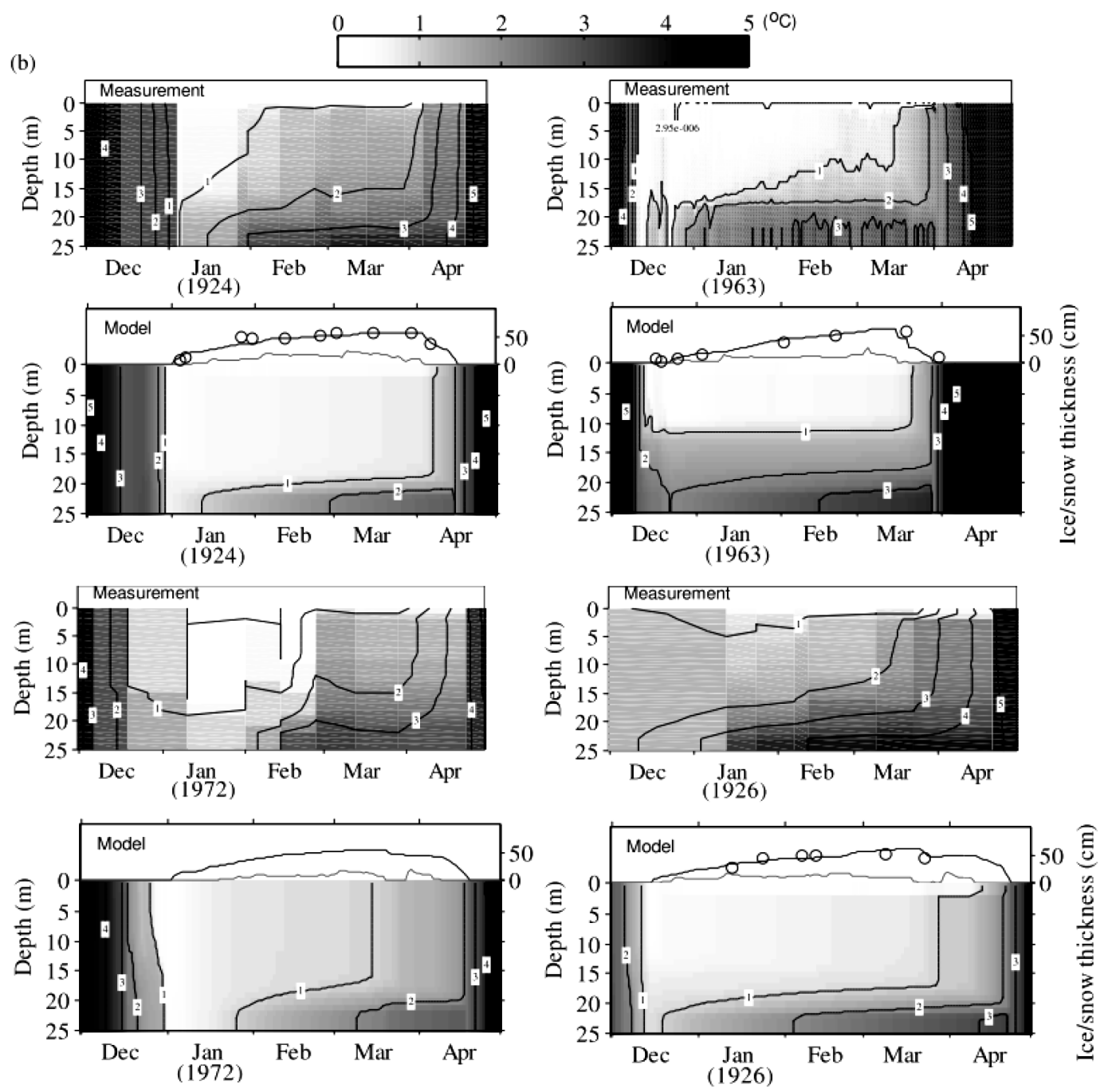

Figure 8. Comparison between the measured and simulated water temperatures and ice/snow thickness under the cold epilimnetic year (1924), warm epilimnetic year (1963), cold hypolimnetic year (1972), and warm hypolimnetic year (1926) in Lake Mendota during the ice-covered period. Time series are simulated ice and snow thickness (solid lines) with measurements (open circles).

(Robertson and Ragotzkie, 1990). Figure 11 shows the dates of onset of stratification breakdown (fall turnover), and the total duration of stratification. The onset dates varied between 17 April (1977) and 30 June (1981), and the date of fall turnover varied from 2 August (1965) to 19 October (2013). Over a century (1911-2014), the onset of thermal stratification has become earlier by 12.3 days $(p<0.05)$, and fall turnover has become later by 14.6 days $(p<0.05)$, resulting in the stratification period increasing by 26.8 days $(p<0.05)$. Stratification onset date shows no significant difference among the three periods (see Table 2); however, the fall turnover date is significantly $(p<0.05)$ different between periods 2 and 3 and between periods 1 and 3 , and the duration of stratification is significantly $(p<0.05)$ different between periods 1 and 3, as shown in Table 2 .
The thermocline depth, defined as the depth of maximum temperature gradient, is determined from the model results (not shown in figure for brevity). During 1911-2014, the midsummer thermocline depth in Lake Mendota varied from 8.3 to $12.4 \mathrm{~m}$ (mean $=10.7 \mathrm{~m}$; $\mathrm{SD}=0.84 \mathrm{~m})$ with no significant long-term change.

\section{Discussion}

\subsection{Significance of lake drivers}

Changes in long-term simulated ice cover and thermal variables in Lake Mendota from 1911-2014 appear to occur over short time frames within this period, synchronous with rapid changes in measured drivers (i.e., air temperature, wind speed, and water clarity). The variables examined included 

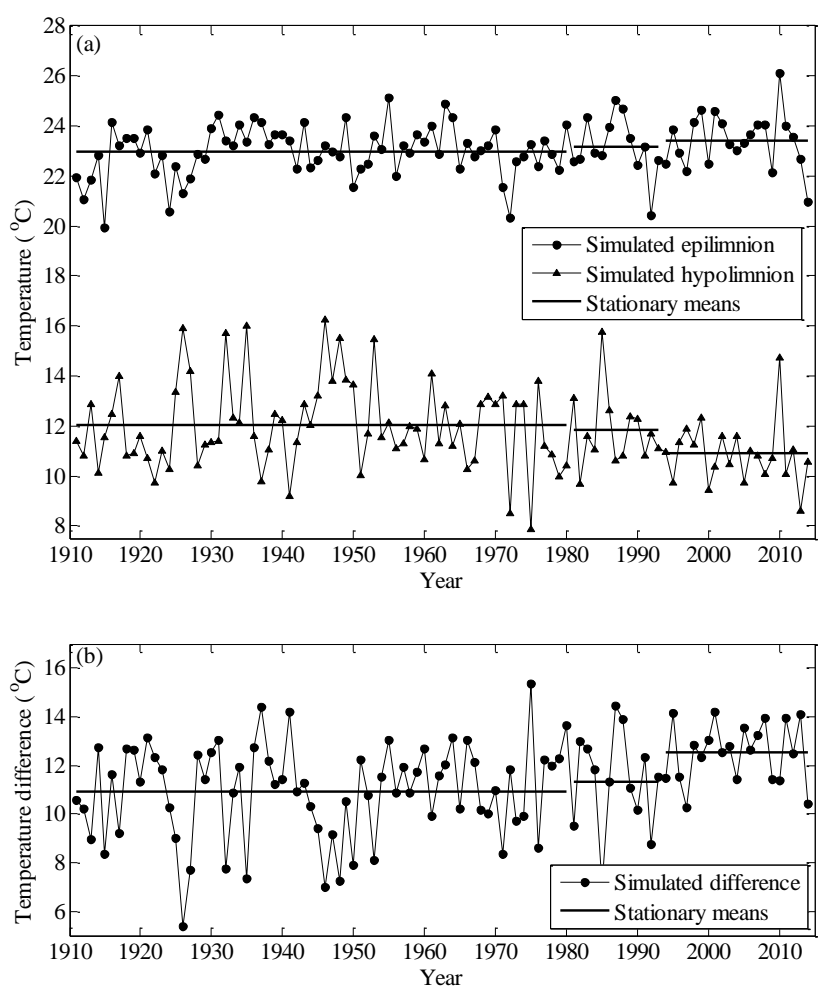

Figure 9. (a) Simulated midsummer (16 July-15 August) volume-averaged epilimnion and hypolimnion temperatures, and (b) epilimnion-hypolimnion temperature difference. Stationary means for three selected periods are denoted by solid lines.

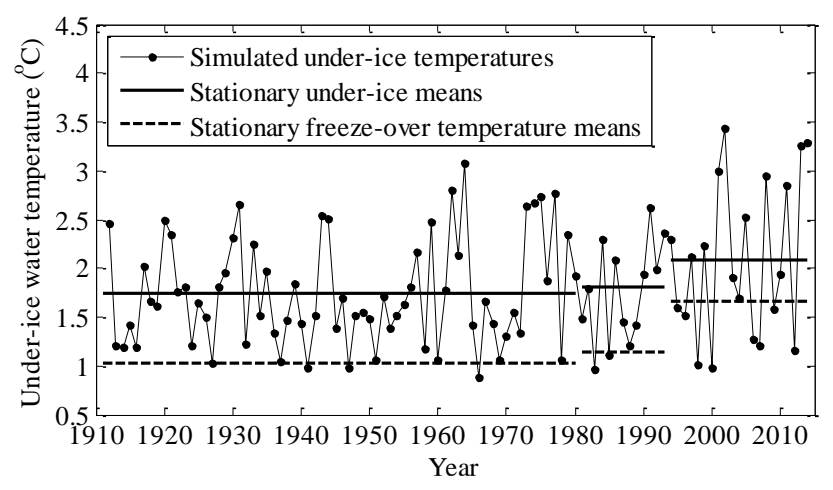

Figure 10. Simulated mean under-ice water temperatures (volumeweighted averages of all depths) during the ice-covered period between 1911 and 2014. The stationary means for three selected periods of under-ice water temperatures and freeze-over water temperatures are also plotted.

ice-on/ice-off dates, maximum ice thickness, freeze-over water temperature, midsummer epilimnetic and hypolimnetic temperatures, summer hypolimnetic heating, and dates of stratification onset and fall turnover. To identify the relationship between the drivers and each of these variables, we employed Pearson correlation analysis on the detrended driver
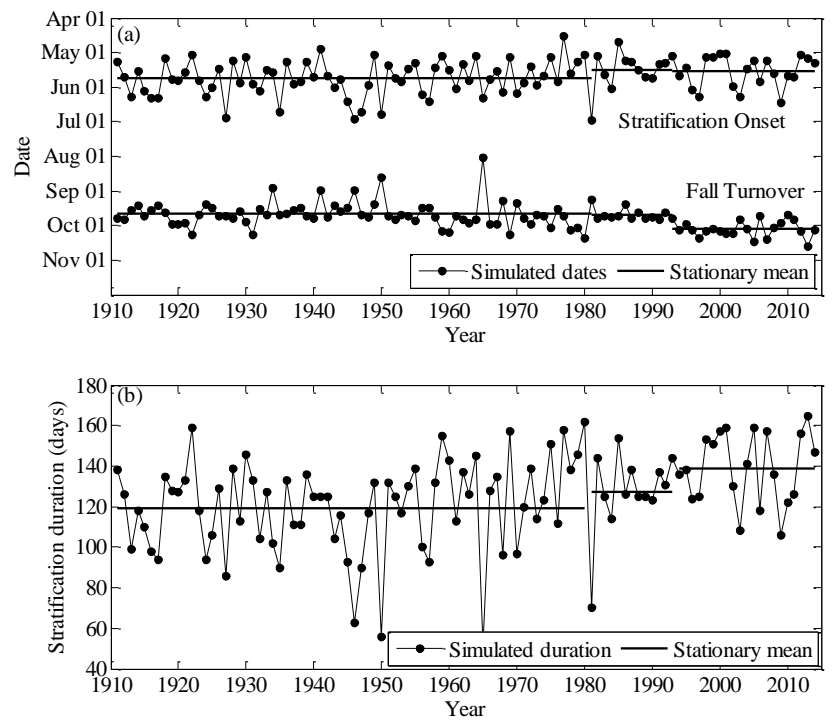

Figure 11. (a) Simulated date of stratification onset and fall turnover and (b) stratification duration. Stationary means for three selected periods are denoted by solid lines.

and simulation data. While using this method does not allow us to directly determine causality, we may identify possible related drivers to changes in lake variables and the relative importance of relationship of three drivers (i.e., air temperature, wind speed, and water clarity) to the lake variables. To calculate correlation coefficients, each lake driver was averaged over a fixed period (e.g., April-May or NovemberDecember) and then paired with each of the simulated lake variables from the same period. The averaging period for air temperature and wind speed was chosen based on the fixed period that yielded the best correlation. We chose to employ fixed periods because thorough testing indicated that using a dynamic period introduced seasonal meteorological variations into the analysis. For instance, the correlation coefficient between onset date and the mean air temperature averaged over the prior month is expected to be high simply due to the seasonal variations over the course of the year, i.e., the later in the spring, the warmer air temperature. Seasonal Secchi depths were compiled for six seasonal periods: winter, spring turnover, early stratification, summer, destratification, and fall turnover (Lathrop et al., 1996), and the period closest to the averaging period used for air temperature and wind speed was used for correlation analysis. The averaging periods used for calculating correlation coefficients of each pair of variables are listed in Table 3. We discuss below the correlations for each pair of variables, shown in Fig. 12.

\subsubsection{Ice cover variables}

Ice-on and ice-off dates have been shown to be sensitive to climate conditions (Livingstone, 1997; Magnuson et al., 2000; Robertson et al., 1992). For both air temperature and 
Table 3. Averaging periods for lake drivers used for calculating correlation coefficients of each pair of variables.

\begin{tabular}{|c|c|c|}
\hline Lake variables & $\begin{array}{l}\text { Air temperature/ } \\
\text { wind speed }\end{array}$ & Secchi depth* \\
\hline Ice-on date & November-December & 13 October - ice-on \\
\hline Ice-off date & February-March & ice-on - ice-off \\
\hline Max. ice thickness & January-March & ice-on - ice-off \\
\hline Freeze-over water temperature & November-December & 13 October - ice-on \\
\hline Date of stratification onset & April-May & ice-off - 10 May \\
\hline Summer epilimnetic temperature & 16 July-15 August & 30 June-2 September \\
\hline Summer hypolimnetic temperature & May & ice-off - 30 June \\
\hline Hypolimnetic heating & July-August & 30 June-2 September \\
\hline Date of fall turnover & September & 3 September-12 October \\
\hline
\end{tabular}

* Six seasonal periods defined in Lathrop et al. (1996).

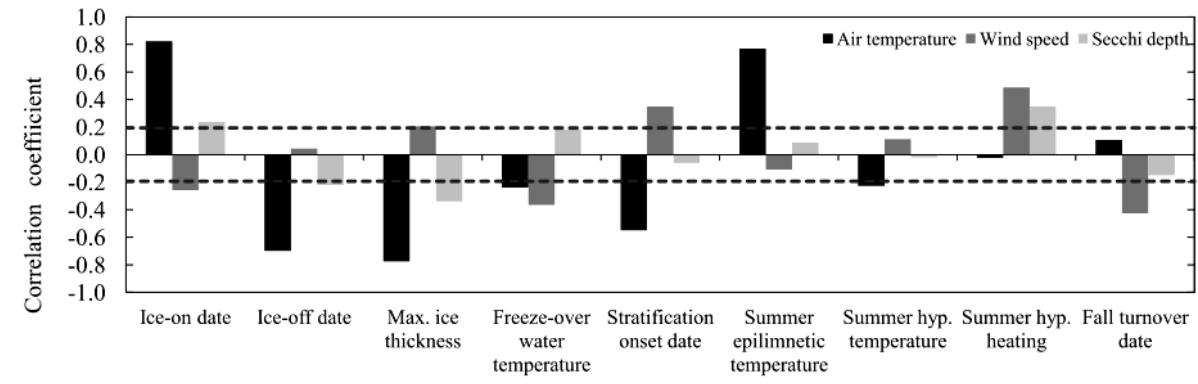

Figure 12. Correlation coefficients between lake variables and drivers. The critical value (dashed lines) for significant correlation $(p<0.05)$ is $0.193(n=104)$.

wind speed, the averages from 1 November to 31 December (N-D) give the highest correlation with ice-on date; in agreement with the results of Assel and Robertson (1995) and similar to Gao and Stefan (1999). Averaged air temperature and wind speed over the period from 1 February to 31 March (FM) provide the highest correlation with ice-off date, consistent with the study by Gao and Stefan (1999), who found that ice-off dates for 10 Minnesota lakes correlated significantly with February-April air temperatures. The strong positive correlation $(r=0.82)$ between ice-on date and N-D air temperature indicates a relationship between warmer N-D air temperatures and later freezing dates. Strong negative correlation between ice-off date and F-M air temperature $(r=-0.70)$ indicates a relationship between earlier ice breakup and warmer F-M air temperatures. In contrast to air temperature, ice cover is only weakly related to the seasonal average wind speed. Nevertheless, the correlation between ice-on date and wind speed $(r=-0.26)$ is significant, indicating a relationship between decreasing wind speed and earlier ice-on dates. Since large wind events prevent ice formation by breaking up skim ice, decreased wind speeds allow ice cover to form slightly earlier in the year. In the Madison area, the decreasing wind speeds may act to slightly mitigate the effects of increasing air temperature in later ice freezing. Correlation between ice dates and Secchi depths is low ( $r=0.24$ for ice-on dates and $r=-0.22$ for ice-off dates), indicating that water clarity has only a minor relationship with ice dates, in agreement with the simulation results of Fang and Stefan (1997). For both ice-on and iceoff dates, correlations with wind speed and Secchi depth are much less significant than with air temperature, indicating that air temperature has a more significant relationship with ice-on and ice-off dates and may be a more significant indicator of ice cover dates and ultimately ice cover duration.

Annual maximum ice thickness is negatively correlated with the 1 January-31 March (J-F-M) averaged air temperature $(r=-0.77)$ and weakly correlated with $\mathrm{J}-\mathrm{F}-\mathrm{M}$ wind speed $(r=0.21)$, indicating a better relationship between annual maximum ice thickness and air temperature than for wind speed. The relationship of air temperatures on ice phenology is consistent with previous findings for lakes in northern Wisconsin, Canada, and Maine (Gao and Stefan, 2004).

The strong correlations between air temperature and ice cover variables agree with several earlier studies (Anderson et al., 1996; Gao and Stefan, 2004; Livingstone, 1997; Vavrus et al., 1996; Williams et al., 2004). Snowfall has also been shown to be related to ice-off date (Jensen et al., 2007) and ice thickness (Duguay et al., 2003; Vavrus et al., 1996) because snowfall changes surface albedo and isolates ice cover from the atmosphere. We found that simulated number of 
snow days (number of days when the lake has snow cover) is strongly correlated with ice-off date $(r=0.70)$ and maximum ice thickness $(r=0.75)$, indicating snowfall is also significantly related to ice cover.

\subsubsection{Water temperature and stratification}

Figure 10 shows that the simulated water temperatures in Lake Mendota at the time of freezing have been increasing since 1911. The correlation between freeze-over water temperature and lake drivers during 1 November and 31 December $(\mathrm{N}-\mathrm{D})$ is significant but with low $r$ values for wind speed $(r=-0.37)$ and air temperature $(r=-0.24)$ and insignificant for Secchi depth $(r=0.18)$. This result indicates that wind mixing is related to cooling of the water column before Lake Mendota freezes.

The simulated onset dates of stratification are negatively correlated with April-May (A-M) air temperature $(r=-0.55)$ and positively correlated with A-M wind speed $(r=0.35)$. In Lake Mendota, the combination of increasing air temperatures and decreasing wind speeds are both related to earlier onset of stratification. Austin and Colman (2007) suggested that the declining ice cover combined with higher air temperatures cause the earlier onset of stratification in

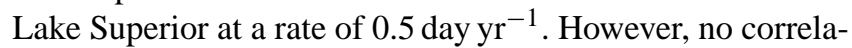
tion between ice-off date and the onset of stratification was found for Lake Mendota in this study.

Midsummer (16 July-15 August) epilimnetic temperatures are most strongly correlated with the air temperature averaged over the corresponding period. Epilimnetic temperature is highly correlated with air temperature $(r=0.77)$ and not significantly correlated with wind speed averaged over the corresponding period $(r=-0.11)$ and Secchi depth $(r=0.09)$. Midsummer hypolimnetic temperatures depend on the timing of stratification (how long the near-bottom water is heated before the onset of stratification) and the amount of heat mixed into hypolimnion before and during the stratification period. Hypolimnetic temperatures are weakly correlated with air temperatures $(r=-0.23)$ and not significantly correlated with wind speed $(r=0.11)$ and Secchi depth $(r=-0.02)$. Summer hypolimnetic heating (temperature change between 1 July and 31 August, J-A) is most strongly correlated with J-A wind speed $(r=0.49)$, moderately correlated with Secchi depth averaged over 30 June2 September $(r=0.35)$, and not significantly correlated with $\mathrm{J}-\mathrm{A}$ air temperature $(r=-0.02)$. This indicates a relationship between stronger winds and clearer water and deeper heat mixing.

Fall turnover occurs when the lake water cools, driven largely by colder air temperature and wind-induced mixing. The date of fall turnover is significantly negatively correlated with September wind speed $(r=-0.43)$ so that higher wind speed is related to earlier fall turnover. Air temperature $(r=0.11)$ and Secchi depth $(r=-0.15)$ are not significantly correlated with the timing of fall mixing. Interestingly, the midsummer epilimnion-hypolimnion temperature difference has a higher correlation with turnover date $(r=0.62)$ than any of the three lake drivers. This finding suggests that the influences of spring conditions may be transmitted to the following summer and fall seasons. In other words, the cooler hypolimnion and the greater epilimnion-hypolimnion temperature difference after a warmer and less windy spring may be related to later fall turnover and a longer stratification period.

\subsection{Abrupt changes in lake variables}

To investigate the effects of abrupt changes in air temperature and wind speed on lake ice cover and water temperatures, we used the hydrodynamic model DYRESM-WQ-I to describe changes in several lake variables during 19112014. Simulation results were used to examine differences in mean values of these lake variables between specific periods (see Sect. 4.1). For each period of the selected periods, mean lake variables were calculated and the differences between periods were analyzed with $t$ tests to determine if they were significantly different. Table 2 lists the mean values and differences for the nine lake variables during the three selected periods. Comparison of period 1 (1911-1980) to period 2 (1981-1993) of lake variables shows a shift to warmer air temperature, period 2 to period 3 (1994-2014) represents an abrupt change to lower wind speed, and period 1 to period 3 represents a shift to warmer air temperature combined with an abrupt change to lower wind speeds.

\subsubsection{Ice cover}

Three simulated ice cover variables (maximum ice thickness, ice-on date, and ice-off date) show no significant difference in means between periods 1 and 2. In other words, the abrupt change in air temperature trend does not result in a different ice period even though the ice cover variables are all highly correlated with air temperature $(r>0.70)$. This may be because the change in air temperatures was not of sufficient magnitude to cause a particularly large change in ice cover or it may signify that other drivers are contributing to changes in ice cover variables. Additionally, no significant difference is observed between period 2 and period 3 for the ice cover variables since the wind speed and ice cover variables are only weakly correlated. The ice variables do show a statistically significant difference in mean values between periods 1 and 3, indicating that a significant shift in these variables occurs only after a sufficiently large increase in air temperature and an abrupt shift in wind speed within the time between periods 1 and 3. In other words, air temperature needs to increase sufficiently to observe a statistically significant difference in ice cover. Ice cover duration, however, shows a significant difference in the mean between all periods $(1-2,2-3$, and 1-3), indicating that distinct differences in ice cover duration can be affected by both trends in air temperature (i.e., 
there was a large-enough change in air temperature between each period) and an abrupt shift in the wind speed. The combined effects of slightly later ice-on dates and earlier ice-off dates during each of the three periods resulted in statistically significant difference in mean ice cover duration values between each of the three periods.

Analysis of simulated maximum ice thickness, ice-on date, ice-off date, and ice cover duration using the method of Rodionov (2004) shows that the most statistically significant timing of the shift in these ice cover variables occurs in the winter of 1997-1998, but a major shift in the air temperature or wind speed data was not observed at that time. The unusual winter of 1997-1998 strongly drove the statistically significant difference in mean values between periods 1 and 3 rather than the abrupt shift in wind speed in 1994. Interestingly, similar results have been reported in Lake Superior, where statistically significant step changes were found in winter ice duration and maximum wintertime ice extent; these step changes account for most of the long-term trends in ice cover for the lake (Van Cleave et al., 2014). The timing of this step change may be attributed to a combination of the longer term changes in meteorological conditions and the short-term annual change occurring in the warm El Niño winter of 19971998 (Van Cleave et al., 2014). Mueller et al. (2009) found that a similar climate shift between 1997 and 1998 initiated a change in lake ice phenology from infrequent to frequent summer loss in several high-Arctic lakes. Similarly, lakes in Poland show a considerable statistical relationship between ice cover and the North Atlantic Oscillation winter indexes (Skowron, 2009), indicating that ice cover may be driven by other large oscillations as well.

\subsubsection{Water temperature and stratification}

Means of five simulated lake variables (under-ice water temperature, freeze-over water temperature, epilimnionhypolimnion temperature difference (indicative of strength of stratification), and duration of stratification) over the three periods have significant $(p<0.05)$ differences only between period 1 and period 3 . This change likely occurs because of the combined effects of large changes in air temperature and a change in wind speed. Both air temperature and wind speed are significantly correlated with these five lake variables. Each driver alone may not be strong enough to cause a major shift in the lake variables, but their combined effects may reinforce the drivers of abrupt change in ice and thermal phenology. Further work is required to examine how the major drivers may either reinforce or dampen lake ice and temperature responses, particularly in relation to directional shifts predicted under climate change.

Fall turnover date, highly correlated with wind speed, exhibits a significant $(p<0.05)$ shift in the mean value in 1994, corresponding with the abrupt shift in the wind speed. Interestingly, hypolimnetic water temperatures, which are not significantly correlated with wind speed, but are correlated with air temperatures, also show a significant $(p<0.05)$ shift in the mean value in 1994. Hypolimnetic heating, significantly correlated with wind speed $(r=0.49)$, does not exhibit a significant breakpoint, nor are any of the mean differences among the three periods significant. Given the high correlation between wind speed and hypolimnetic heating, it is hypothesized that there should be a shift in hypolimnetic heating caused by the abrupt shift in wind speed in 1994. The lack of statistically significant step change may be explained by the simultaneous high correlation between Secchi depth and hypolimnetic heating $(r=0.35)$, indicating that water clarity may act to inhibit heating regardless of changes in wind speed, or it may be acting to filter or mitigate the effects of the wind speed shift. Finally, mean onset date of stratification and midsummer epilimnetic temperature exhibit no difference among the three periods. This may be due to two processes: (i) the climate signal is being filtered out by the lake or (ii) the external perturbation of the system is not yet strong enough to trigger a major shift in the system's internal dynamics.

\subsection{Ecological significance of long-term changes in lake variables}

Changes in lake ice cover and thermal structure are of great ecological significance. Summer stratification inhibits the vertical transport of oxygen and nutrients. The vertical temperature gradient in Lake Mendota increased (Fig. 9b), which should decrease the depth of vertical mixing and oxygen penetration and decrease the transport of nutrients from the hypolimnion to the epilimnion (Fee et al., 1994). Thus, increases in air temperature may increase the epilimnetichypolimnetic temperature gradient and decrease the extent of summer algal blooms in the Lake Mendota where internal loading of phosphorus has been shown to be significant to its summer phosphorus budget (Lathrop et al., 1998; Soranno et al., 1997). Additionally, phosphorus entrainment predominately occurs during periods of high wind (Kamarainen et al., 2009; Stauffer and Armstrong, 1986). Algal blooms have been associated with increases in epilimnetic phosphorus due to these high-wind episodes (Robarts et al., 1998; Soranno et al., 1997; Stauffer and Lee, 1973). Changes in the frequency of high-wind episodic events may further impact the growth of algal blooms within Lake Mendota (Kara et al., 2012). Elevated water temperatures can affect plankton community composition and abundance (Elliot et al., 2005; Findlay et al., 2001; Francis et al., 2014; Rice et al., 2015) and fish populations (Carpenter et al., 1992; De Stasio et al., 1996; Gunn, 2002; Magnuson et al., 1990). High water temperatures have been also shown to enhance the dominance of cyanobacteria (Huber et al., 2008; Jöhnk et al., 2008). Such changes in algal blooms, zooplankton populations, and fish populations may have drastic effects on the overall food web within Lake Mendota (Carpenter et al., 1998). Variations in ice cover conditions have impacts on ecosystems by dramatically chang- 
ing habitat factors such as light and temperature (Adrian et al., 1999; Quayle et al., 2002). Such changes impact the distribution, behavior, community composition, reproduction, and evolutionary adaptations of organisms (Sala et al., 2000). Previous studies have shown that climate change will likely affect the biodiversity of freshwater ecosystems (Heino et al., 2009; Mantyka-Pringle et al., 2014; Wrona et al., 2006). Climate change can bring asynchronies in biotic communities that may result in a phenological decoupling of trophic relationships (Stenseth and Mysterud, 2002).

\section{Conclusions}

The one-dimensional hydrodynamic ice model, DYRESMWQ-I, is developed and validated, then used to simulate the ice cover and thermal structure of Lake Mendota, WI from 1911-2014. The model reliably reproduces the interannual variations and long-term (104-year) changes in ice cover and thermal structure. To our knowledge, this study presents the first attempt to continuously model both ice cover and thermal structure of a lake over a period as long as a century. Simulated ice cover over this period has changed dramatically: freezing later ( 9.0 days per century), breaking up earlier (12.3 days per century), resulting in shorter ice duration (21.3 days per century), and thinner maximum ice thickness (12.7 $\mathrm{cm}$ per century). These results agree well with the observed data and previous studies. For lake thermal structure, results of the continuous model simulation indicate an earlier onset of thermal stratification (12.3 days per century), later fall turnover (14.6 days per century), and a longer stratification period (26.8 days per century) during this period. In addition, simulated midsummer hypolimnetic temperature decreased $\left(-1.4^{\circ} \mathrm{C}\right.$ per century), causing midsummer epilimnetic-hypolimnetic temperature differences (strength of stratification) to increase $\left(2.0^{\circ} \mathrm{C}\right.$ per century). Interestingly, there is no significant trend in midsummer epilimnetic temperatures.

Correlations comparing simulated lake conditions with seasonally averaged meteorological conditions indicate that, among the three drivers, air temperature has the largest relationship with the ice cover variables (ice-on and ice-off dates, and maximum ice thickness) and with three stratification variables (date of the onset of stratification, epilimnetic temperatures, and hypolimnetic temperatures). Freezeover water temperature, summer hypolimnetic heating, and date of fall turnover all have the largest correlation with wind speed. Both air temperature and wind speeds are highly correlated with the onset of stratification. Secchi depth does not appear to have a strong relationship with interannual variability of these variables for Lake Mendota, but in combination with wind speed may be related to hypolimnetic heating.

Changes in meteorological factors over the past 104 years were examined to determine if there have been abrupt shifts, rather than linear changes. Based on a change in the trend of air temperature increase occurring in 1981 and a major shift in wind speed in 1994, the Madison climate is divided into three distinct periods: 1911-1980, with relatively low air temperatures and mean wind speeds of $4.44 \mathrm{~m} \mathrm{~s}^{-1}$; $1981-$ 1993, with higher air temperatures and mean wind speeds of $4.44 \mathrm{~m} \mathrm{~s}^{-1}$; and 1994-2014 with still higher air temperatures and mean wind speed of $3.74 \mathrm{~m} \mathrm{~s}^{-1}$. Ice cover duration exhibited a significant difference in the mean among all three periods, while ice-on date, ice-off date, and maximum ice thickness only show a significant difference between periods 1 and 3, indicating that only with a large change in air temperature and an abrupt shift in wind speeds are change in the ice cover variables statistically different. Midsummer hypolimnetic temperature and fall turnover date both reveal significant $(p<0.05)$ differences in the mean value in 1994, corresponding with the abrupt shift toward lower wind speeds. Some lake variables (under-ice water temperature, freeze-over water temperature, epilimnionhypolimnion temperature difference, and stratification duration) may not be driven by either the change in air temperature trend or the abrupt shift in wind speed alone, but a shift in the mean of the lake variables does occur in 1994 when both the air temperatures are warmest and the wind speed experienced an abrupt shift. The exact timing of shifts may be difficult to define because of extreme changes in weather in specific years and it may mask the longer term changes in meteorological conditions (i.e., abrupt shifts).

Linear trends from the extensive data collection may be misleading as they masks these sudden shifts in the air temperature and wind speed drivers and lake ice cover and thermal structure variables. Examining the mean differences in lake variables in response to shifts in air temperature and abrupt shifts in wind speeds provide a better understanding of how the southern Wisconsin climate has changed and what impact those changes have on shifts in the ice cover and water temperature of dimictic Lake Mendota. It is shown that air temperature and wind speed changes have occurred in stages and lake variables have responded in a nonlinear way to these changes.

Acknowledgements. Financial support for this project was provided in part by the US National Science Foundation Long-Term Ecological Research Program, University of Wisconsin (UW) Water Resources Institutes USGS 104(B) Research Project, and UW Office of Sustainability SIRE Award Program. Funding support for the first author by the College of Engineering Grainger Wisconsin Distinguished Graduate Fellowship is acknowledged. We thank Yi-Fang Hsieh for further developing an ice module in the DYRESM-WQ model in work that was initiated by Brett Wallace. We acknowledge Yi-Fang Hsieh for collecting ice data used for the model calibration and validation in this study. Finally, the authors would like to thank John Magnuson and Tim Kratz at the Center for Limnology for their insightful suggestions regarding climate change on lake ice. Last but not least, we acknowledge the editor Marnik Vanclooster and the three reviewers, Renjie Xia, 
Roman Zurek, and Homa Kheyrollah Pour, for their valuable and constructive comments to greatly improve the paper.

Edited by: M. Vanclooster

\section{References}

Adrian, R., Walz, N., Hintze, T., Hoeg, S., and Rusche, R.: Effects of ice duration on plankton succession during spring in a shallow polymictic lake, Freshwater Biol., 41, 621-634, doi:10.1046/j.1365-2427.1999.00411.x, 1999.

Anderson, W. L., Robertson, D. M., and Magnuson, J. J.: Evidence of recent warming and El Niño-related variations in ice breakup of Wisconsin lakes, Limnol. Oceanogr., 41, 815-821, doi:10.4319/lo.1996.41.5.0815, 1996.

Antenucci, J. and Imerito, A.: The CWR Dynamic Reservoir Simulation Model DYRESM: User Manual Place of publication: Crawley, WA, Australia, The University of Western Australia, Centre for Water Research, 1-41, 2003.

Arhonditsis, G. B., Brett, M. T., DeGasperi, C. L., and Schindler, D. E.: Effects of Climatic Variability on the Thermal Properties of Lake Washington, Limnol. Oceanogr., 49, 256-270, 2004a.

Arhonditsis, G. B., Winder, M., Brett, M. T., and Schindler, D. E.: Patterns and mechanisms of phytoplankton variability in Lake Washington (USA), Water Res., 38, 4013-4027, doi:10.1016/j.watres.2004.06.030, 2004b.

Ashton, G. D.: River and lake ice engineering, Water Resources Publications, Littleton, Colorado, 19-256, 1986.

Assel, R. A. and Robertson, D. M.: Changes in winter air temperatures near Lake Michigan, 1851-1993, as determined from regional lake-ice records, Limnol. Oceanogr., 40, 165-176, doi:10.4319/lo.1995.40.1.0165, 1995.

Austin, J. A. and Colman, S. M.: Lake Superior summer water temperatures are increasing more rapidly than regional air temperatures: A positive ice-albedo feedback, Geophys. Res. Lett., 34, L06604, doi:10.1029/2006GL029021, 2007.

Bengtsson, L.: Spatial Variability of Lake Ice Covers, Geogr. Ann. Ser. Phys. Geogr., 68, 113-121, doi:10.2307/521182, 1986.

Birge, E. A., Juday, C., and March, H. W.: The temperature of the bottom deposits of Lake Mendota, in: a chapter in the heat exchanges of the lake, Trans. Wis. Acad. Sci. Arts Lett., XXIII, available at: http://digicoll.library.wisc.edu/cgi-bin/WI/WI-idx?type= article\&did=WI.WT1927.EABaird\&id=WI.WT1927\&isize $=\mathrm{M}$ (last access: 1 October 2015), 1927.

Brown, R. W., Taylor, W. W., and Assel, R. A.: Factors Affecting the Recruitment of Lake Whitefish in Two Areas of Northern Lake Michigan, J. Gt. Lakes Res., 19, 418-428, doi:10.1016/S03801330(93)71229-0, 1993.

Butcher, J. B., Nover, D., Johnson, T. E., and Clark, C. M.: Sensitivity of lake thermal and mixing dynamics to climate change, Climatic Change, 129, 295-305, doi:10.1007/s10584-015-13261, 2015.

Carpenter, S. R., Fisher, S. G., Grimm, N. B., and Kitchell, J. F.: Global change and freshwater ecosystems, Annu. Rev. Ecol. Syst., 23, 119-139, 1992.

Carpenter, S. R., Olson, M., Cunningham, P., Gafny, S., Nibbelink, N., Pellett, T., Storlie, C., Trebitz, A., and Wilson, K.: Macro- phyte Structure and Growth of Bluegill (Lepomis macrochirus): Design of a Multilake Experiment, in: The Structuring Role of Submerged Macrophytes in Lakes, edited by: Jeppesen, E., Søndergaard, M., Søndergaard, M., and Christoffersen, K., Springer, New York, 217-226, available at: http://link.springer. com/chapter/10.1007/978-1-4612-0695-8_11 (last access: 1 October 2015), 1998.

Choiński, A., Kolendowicz, L., Pociask-Karteczka, J., and Sobkowiak, L.: Changes in Lake Ice Cover on the Morskie Oko Lake in Poland (1971-2007), Adv. Clim. Change Res., 1, 71-75, doi:10.3724/SP.J.1248.2010.00071, 2010.

Choiński, A., Ptak, M., and Strzelczak: Areal variation in ice cover thickness on lake morskie oko (Tatra mountains), Carpath. J. Earth Environ. Sci., 8, 97-102, 2013.

Desai, A. R., Austin, J. A., Bennington, V., and McKinley, G. A.: Stronger winds over a large lake in response to weakening air-to-lake temperature gradient, Nat. Geosci., 2, 855-858, doi:10.1038/ngeo693, 2009.

De Stasio, B. T., Hill, D. K., Kleinhans, J. M., Nibbelink, N. P., and Magnuson, J. J.: Potential effects of global climate change on small north-temperate lakes: Physics, fish, and plankton, Limnol. Oceanogr., 41, 1136-1149, doi:10.4319/lo.1996.41.5.1136, 1996.

Dobiesz, N. E. and Lester, N. P.: Changes in mid-summer water temperature and clarity across the Great Lakes between 1968 and 2002, J. Gt. Lakes Res., 35, 371-384, doi:10.1016/j.jglr.2009.05.002, 2009.

Duguay, C. R., Flato, G. M., Jeffries, M. O., Ménard, P., Morris, K., and Rouse, W. R.: Ice-cover variability on shallow lakes at high latitudes: model simulations and observations, Hydrol. Process., 17, 3465-3483, doi:10.1002/hyp.1394, 2003.

Elliot, A. J., Thackeray, S. J., Huntingford, C., and Jones, R. G.: Combining a regional climate model with a phytoplankton community model to predict future changes in phytoplankton in lakes, Freshwater Biol., 50, 1404-1411, doi:10.1111/j.13652427.2005.01409.x, 2005.

Ellis, C. R., Stefan, H. G., and Gu, R.: Water Temperature Dynamics and Heat Transfer Beneath the Ice Cover of a Lake, Limnol. Oceanogr., 36, 324-335, 1991.

Fang, X. and Stefan, H. G.: Dynamics of heat exchange between sediment and water in a lake, Water Resour. Res., 32, 1719-1727, doi:10.1029/96WR00274, 1996a.

Fang, X. and Stefan, H. G.: Long-term lake water temperature and ice cover simulations/measurements, Cold Reg. Sci. Technol., 24, 289-304, doi:10.1016/0165-232X(95)00019-8, 1996b.

Fang, X. and Stefan, H. G.: Simulated climate change effects on dissolved oxygen characteristics in ice-covered lakes, Ecol. Model., 103, 209-229, doi:10.1016/S0304-3800(97)00086-0, 1997.

Fang, X. and Stefan, H. G.: Simulations of climate effects on water temperature, dissolved oxygen, and ice and snow covers in lakes of the contiguous U.S. under past and future climate scenarios, Limnol. Oceanogr., 54, 2359-2370, doi:10.4319/lo.2009.54.6_part_2.2359, 2009.

Fee, E. J., Hecky, R. E., Regehr, G. W., Hendzel, L. L., and Wilkinson, P.: Effects of Lake Size on Nutrient Availability in the Mixed Layer during Summer Stratification, Can. J. Fish. Aquat. Sci., 51, 2756-2768, doi:10.1139/f94-276, 1994.

Fee, E. J., Hecky, R. E., Kasian, S. E. M., and Cruikshank, D. R.: Effects of lake size, water clarity, and climatic variability on mixing 
depths in Canadian Shield lakes, Limnol. Oceanogr., 41, 912920, doi:10.4319/lo.1996.41.5.0912, 1996.

Findlay, D. L., Kasian, S. E. M., Stainton, M. P., Beaty, K., and Lyng, M.: Climatic influences on algal populations of boreal forest lakes in the Experimental Lakes Area, Limnol. Oceanogr., 46, 1784-1793, doi:10.4319/lo.2001.46.7.1784, 2001.

Francis, T. B., Wolkovich, E. M., Scheuerell, M. D., Katz, S. L., Holmes, E. E., and Hampton, S. E.: Shifting Regimes and Changing Interactions in the Lake Washington, U.S.A., Plankton Community from 1962-1994, PLoS ONE, 9, e110363, doi:10.1371/journal.pone.0110363, 2014.

Fu, G., Charles, S. P., and Yu, J.: A critical overview of pan evaporation trends over the last 50 years, Climatic Change, 97, 193-214, doi:10.1007/s10584-009-9579-1, 2009.

Gao, S. and Stefan, H. G.: Multiple Linear Regression for Lake Ice and Lake Temperature Characteristics, J. Cold Reg. Eng., 13, 5977, doi:10.1061/(ASCE)0887-381X(1999)13:2(59), 1999.

Gao, S. and Stefan, H. G.: Potential Climate Change Effects on Ice Covers of Five Freshwater Lakes, J. Hydrol. Eng., 9, 226-234, doi:10.1061/(ASCE)1084-0699(2004)9:3(226), 2004.

Gunn, J. M.: Impact of the 1998 El Niño event on a Lake Charr, Salvelinus Namaycush, Population Recovering from Acidification, Environ. Biol. Fishes, 64, 343-351, doi:10.1023/A:1016058606770, 2002.

Hamilton, D. P. and Schladow, S. G.: Prediction of water quality in lakes and reservoirs. Part I - Model description, Ecol. Model., 96, 91-110, doi:10.1016/S0304-3800(96)00062-2, 1997.

Hartmann, D. L., Klein Tank, A. M. G., Rusticucci, M., Alexander, L. V., Brönnimann, S., Charabi, Y., Dentener, F. J., Dlugokencky, E. J., Easterling, D. R., Kaplan, A., Soden, B. J., Thorne, P. W., Wild, M., and Zhai, P. M.: Observations: Atmosphere and Surface in Climate change 2013, in: Working Group I contribution to the Fifth assessment report of the Intergovernmental Panel on Climate Change, edited by: Stocker, T., Qin, D., Plattner, G.-K., Tignor, M., Allen, S. K., Boschung, J., Nauels, A., Xia, Y., Bex, V., and Midgley, P. M., Cambridge University Press, New York, NY, USA, 187-197, 2013.

Heino, J., Virkkala, R., and Toivonen, H.: Climate change and freshwater biodiversity: detected patterns, future trends and adaptations in northern regions, Biol. Rev., 84, 39-54, doi:10.1111/j.1469-185X.2008.00060.x, 2009.

Hill, J. M. and Kucera, A.: Freezing a saturated liquid inside a sphere, Int. J. Heat Mass Transf., 26, 1631-1637, doi:10.1016/S0017-9310(83)80083-0, 1983.

Hocking, G. C. and Straškraba, M.: The Effect of Light Extinction on Thermal Stratification in Reservoirs and Lakes, Int. Rev. Hydrobiol., 84, 535-556, doi:10.1002/iroh.199900046, 1999.

Hsieh, Y.: Modeling ice cover and water temperature of Lake Mendota, PhD Thesis, University of Wisconsin-Madison, Madison, Wisconsin, USA, 6-49, 2012.

Huber, V., Adrian, R., and Gerten, D.: Phytoplankton response to climate warming modified by trophic state, Limnol. Oceanogr., 53, 1-13, doi:10.4319/lo.2008.53.1.0001, 2008.

Imberger, J. and Patterson, J. C.: Dynamic reservoir simulation model - DYRESM: 5, in: Transport Models for Inland and Coastal Waters, edited by: Fischer, H. B., Academic Press, New York, 310-361, 1981.

IPCC: Summary for Policymakers, in: Climate Change 2013: The Physical Science Basis, Contribution of Working Group I to the
Fifth Assessment Report of the Intergovernmental Panel on Climate Change, edited by: Stocker, T., Qin, D., Plattner, G.-K., Tignor, M., Allen, S. K., Boschung, J., Nauels, A., Xia, Y., Bex, V., and Midgley, P. M., Cambridge University Press, New York, NY, USA, 3-29, 2013.

Jensen, O. P., Benson, B. J., Magnuson, J. J., Card, V. M., Futter, M. N., Soranno, P. A., and Stewart, K. M.: Spatial analysis of ice phenology trends across the Laurentian Great Lakes region during a recent warming period, Limnol. Oceanogr., 52, 20132026, doi:10.4319/lo.2007.52.5.2013, 2007.

Jiang, Y., Luo, Y., Zhao, Z., and Tao, S.: Changes in wind speed over China during 1956-2004, Theor. Appl. Climatol., 99, 421-430, doi:10.1007/s00704-009-0152-7, 2009.

Jöhnk, K. D., Huisman, J., Sharples, J., Sommeijer, B., Visser, P. M., and Stroom, J. M.: Summer heatwaves promote blooms of harmful cyanobacteria, Global Change Biol., 14, 495-512, doi:10.1111/j.1365-2486.2007.01510.x, 2008.

Kamarainen, A., Yuan, H. L, Wu, C. H., and Carpenter, S. R.: Estimates of phosphorus entrainment in Lake Mendota: A comparison of one-dimensional and three-dimensional approaches, Limnol. Oceanogr., 7, 553-567, 2009.

Kara, E. L., Hanson, P., Hamilton, D., Hipsey, M. R., McMahon, K. D., Read, J. S., Winslow, L., Dedrick, J., Rose, K., Carey, C. C., Bertilsson, S., da Motta Marques, D., Beversdorf, L., Miller, T., Wu, C., Hsieh, Y.-F., Gaiser, E., and Kratz, T.: Time-scale dependence in numerical simulations: Assessment of physical, chemical, and biological predictions in a stratified lake at temporal scales of hours to months, Environ. Model. Softw., 35, 104-121, doi:10.1016/j.envsoft.2012.02.014, 2012.

King, J. R., Shuter, B. J., and Zimmerman, A. P.: The response of the thermal stratification of South Bay (Lake Huron) to climatic variability, Can. J. Fish. Aquat. Sci., 54, 1873-1882, doi:10.1139/f97-093, 1997.

Kitchell, J. F.: Food Web Management: A Case Study of Lake Mendota, Springer Science \& Business Media, New York, NY, USA 18-27, 1992.

Klink, K.: Trends and Interannual Variability of Wind Speed Distributions in Minnesota, J. Climate, 15, 3311-3317, doi:10.1175/1520-0442(2002)015<3311:TAIVOW>2.0.CO;2, 2002.

Kucharik, C. J., Serbin, S. P., Vavrus, S., Hopkins, E. J., and Motew, M. M.: Patterns of Climate Change Across Wisconsin From 1950 to 2006, Phys. Geogr., 31, 1-28, doi:10.2747/0272-3646.31.1.1, 2010.

Lathrop, R. C., Carpenter, S. R., and Rudstam, L. G.: Water clarity in Lake Mendota since 1900: responses to differing levels of nutrients and herbivory, Can. J. Fish. Aquat. Sci., 53, 2250-2261, doi:10.1139/f96-187, 1996.

Lathrop, R. C., Carpenter, S. R., Stow, C. A., Soranno, P. A., and Panuska, J. C.: Phosphorus loading reductions needed to control blue-green algal blooms in Lake Mendota, Can. J. Fish. Aquat. Sci., 55, 1169-1178, doi:10.1139/f97-317, 1998.

Liu, Y., Wu, G., and Zhao, X.: Recent declines in China's largest freshwater lake: trend or regime shift?, Environ. Res. Lett., 8, 014010, doi:10.1088/1748-9326/8/1/014010, 2013.

Livingstone, D. M.: Break-up Dates of Alpine Lakes As Proxy Data for Local and Regional Mean Surface Air Temperatures, Climatic Change, 37, 407-439, doi:10.1023/A:1005371925924, 1997. 
Lynch, A. J., Taylor, W. W., Beard Jr., T. D., and Lofgren, B. M.: Climate change projections for lake whitefish (Coregonus clupeaformis) recruitment in the 1836 Treaty Waters of the Upper Great Lakes, J. Gt. Lakes Res., 41, 415-422, doi:10.1016/j.jglr.2015.03.015, 2015.

Magnuson, J. J., Benson, B. J., and Kratz, T. K.: Temporal coherence in the limnology of a suite of lakes in Wisconsin, U.S.A., Freshwater Biol., 23, 145-159, doi:10.1111/j.13652427.1990.tb00259.x, 1990.

Magnuson, J. J., Webster, K. E., Assel, R. A., Bowser, C. J., Dillon, P. J., Eaton, J. G., Evans, H. E., Fee, E. J., Hall, R. I., Mortsch, L. R., Schindler, D. W., and Quinn, F. H.: Potential Effects of Climate Changes on Aquatic Systems: Laurentian Great Lakes and Precambrian Shield Region, Hydrol. Process., 11, 825-871, doi:10.1002/(SICI)10991085(19970630)11:8<825::AID-HYP509>3.0.CO;2-G, 1997.

Magnuson, J. J., Robertson, D. M., Benson, B. J., Wynne, R. H., Livingstone, D. M., Arai, T., Assel, R. A., Barry, R. G., Card, V., Kuusisto, E., Granin, N. G., Prowse, T. D., Stewart, K. M., and Vuglinski, V. S.: Historical Trends in Lake and River Ice Cover in the Northern Hemisphere, Science, 289, 1743-1746, doi:10.1126/science.289.5485.1743, 2000.

Maidment, D. R.: Handbook of hydrology, McGraw-Hill, New York 18-1-19-1, 1993.

Mantyka-Pringle, C. S., Martin, T. G., Moffatt, D. B., Linke, S., and Rhodes, J. R.: Understanding and predicting the combined effects of climate change and land-use change on freshwater macroinvertebrates and fish, J. Appl. Ecol., 51, 572-581, doi:10.1111/1365-2664.12236, 2014.

Marszelewski, W. and Skowron, R.: Ice cover as an indicator of winter air temperature changes: case study of the Polish Lowland lakes, Hydrolog. Sci. J., 51, 336-349, doi:10.1623/hysj.51.2.336, 2006.

Mazumder, A. and Taylor, W. D.: Thermal structure of lakes varying in size and water clarity, Limnol. Oceanogr., 39, 968-976, doi:10.4319/lo.1994.39.4.0968, 1994.

McKay, G.: Problems of measuring and evaluating snow cover, in: Proceedings Workshop Seminar of Snow Hydrology, Ottawa, Canada, 49-63, 1968.

McKee, T. B., Doesken, N. J., Davey, C. A. and Pielke, Sr.: Climate data continuity with ASOS, Report for period April 1996 through June 2000, Colorado Climate Center, Department of Atmospheric Science, Colorado State University, Fort Collins, CO, Climatology Report No. 00-3, 77 pp., 2000.

Mueller, D. R., Van Hove, P., Antoniades, D., Jeffries, M. O., and Vincent, W. F.: High Arctic lakes as sentinel ecosystems: Cascading regime shifts in climate, ice cover, and mixing, Limnol. Oceanogr., 54, 2371-2385, doi:10.4319/lo.2009.54.6_part_2.2371, 2009.

North, R. P., Livingstone, D. M., Hari, R. E., Koster, O., Niederhauser, P., and Kipfer, R.: The physical impact of the late 1980s climate regime shift on Swiss rivers and lakes, Inland Waters, 3, 341-350, doi:10.5268/IW-3.3.560, 2013.

North, R. P., North, R. L., Livingstone, D. M., Köster, O., and Kipfer, R.: Long-term changes in hypoxia and soluble reactive phosphorus in the hypolimnion of a large temperate lake: consequences of a climate regime shift, Global Change Biol., 20, 811-823, doi:10.1111/gcb.12371, 2014.
Patterson, J. C. and Hamblin, P. F.: Thermal simulation of a lake with winter ice cover, Limnol. Oceanogr., 33, 323-338, doi:10.4319/lo.1988.33.3.0323, 1988.

Pryor, S. C., Barthelmie, R. J., Young, D. T., Takle, E. S., Arritt, R. W., Flory, D., Gutowski, W. J., Nunes, A., and Roads, J.: Wind speed trends over the contiguous United States, J. Geophys. Res.Atmos., 114, D14105, doi:10.1029/2008JD011416, 2009.

Quayle, W. C., Peck, L. S., Peat, H., Ellis-Evans, J. C., and Harrigan, P. R.: Extreme Responses to Climate Change in Antarctic Lakes, Science, 295, 645-645, doi:10.1126/science.1064074, 2002.

Read, J. S., Hamilton, D. P., Desai, A. R., Rose, K. C., MacIntyre, S., Lenters, J. D., Smyth, R. L., Hanson, P. C., Cole, J. J., Staehr, P. A., Rusak, J. A., Pierson, D. C., Brookes, J. D., Laas, A., and Wu, C. H.: Lake-size dependency of wind shear and convection as controls on gas exchange, Geophys. Res. Lett., 39, L09405, doi:10.1029/2012GL051886, 2012.

Rempfer, J., Livingstone, D. M., Blodau, C., Forster, R., Niederhauser, P., and Kipfer, R.: The effect of the exceptionally mild European winter of 2006-2007 on temperature and oxygen profiles in lakes in Switzerland: A foretaste of the future?, Limnol. Oceanogr., 55, 2170-2180, doi:10.4319/lo.2010.55.5.2170, 2010.

Rice, E., Dam, H. G., and Stewart, G.: Impact of Climate Change on Estuarine Zooplankton: Surface Water Warming in Long Island Sound Is Associated with Changes in Copepod Size and Community Structure, Estuar. Coasts, 38, 13-23, doi:10.1007/s12237014-9770-0, 2015.

Robarts, R. D., Waiser, M. J., Hadas, O., Zohary, T., and Maclntyre, S.: Relaxation of phosphorus limitation due to typhoon-induced mixing in two morphologically distinct basins of Lake Biwa, Japan, Limnol. Oceanogr., 43, 1023-1036, doi:10.4319/lo.1998.43.6.1023, 1998.

Robertson, D. M.: The use of lake water temperature and ice cover as climatic indicators, $\mathrm{PhD}$ Thesis, University of WisconsinMadison, Madison, Wisconsin, USA, 330 pp., 1989.

Robertson, D. M. and Ragotzkie, R. A.: Changes in the thermal structure of moderate to large sized lakes in response to changes in air temperature, Aquat. Sci., 52, 360-380, doi:10.1007/BF00879763, 1990.

Robertson, D. M., Ragotzkie, R. A., and Magnuson, J. J.: Lake ice records used to detect historical and future climatic changes, Climatic Change, 21, 407-427, doi:10.1007/BF00141379, 1992.

Robertson, D. M., Wynne, R. H., and Chang, W. Y. B.: Variability in ice cover across the northern hemisphere during the 1900's associated with El Nino events, Proc. Int. Limnol. Soc., 27842788, Stuttgart, 2002.

Rodionov, S. N.: A sequential algorithm for testing climate regime shifts, Geophys. Res. Lett., 31, L09204, doi:10.1029/2004GL019448, 2004.

Rodionov, S. N.: The problem of red noise in climate regime shift detection, Geophys. Res. Lett., 31, L12707, doi:10.1029/2006GL025904, 2006.

Rogers, C. K., Lawrence, G. A., and Hamblin, P. F.: Observations and numerical simulation of a shallow icecovered midlatitude lake, Limnol. Oceanogr., 40, 374-385, doi:10.4319/lo.1995.40.2.0374, 1995.

Sala, O. E., Chapin, F. S., Iii, Armesto, J. J., Berlow, E., Bloomfield, J., Dirzo, R., Huber-Sanwald, E., Huenneke, L. F., Jackson, R. B., 
Kinzig, A., Leemans, R., Lodge, D. M., Mooney, H. A., Oesterheld, M., Poff, N. L., Sykes, M. T., Walker, B. H., Walker, M., and Wall, D. H.: Global Biodiversity Scenarios for the Year 2100, Science, 287, 1770-1774, doi:10.1126/science.287.5459.1770, 2000.

Scheffer, M., Carpenter, S., Foley, J. A., Folke, C., and Walker, B.: Catastrophic shifts in ecosystems, Nature, 413, 591-596, doi:10.1038/35098000, 2001.

Schindler, D. W., Beaty, K. G., Fee, E. J., Cruikshank, D. R., Debruyn, E. R., Findlay, D. L., Linsey, G. A., Shearer, J. A., Stainton, M. P., and Turner, M. A.: Effects of climatic warming on lakes of the central boreal forest, Science, 250, 967-970, doi:10.1126/science.250.4983.967, 1990.

Schindler, D. W., Bayley, S. E., Parker, B. R., Beaty, K. G., Cruikshank, D. R., Fee, E. J., Schindler, E. U., and Stainton, M. P.: The effects of climatic warming on the properties of boreal lakes and streams at the Experimental Lakes Area, northwestern Ontario, Limnol. Oceanogr., 41, 1004-1017, doi:10.4319/lo.1996.41.5.1004, 1996.

Schneider, P. and Hook, S. J.: Space observations of inland water bodies show rapid surface warming since 1985, Geophys. Res. Lett., 37, L22405, doi:10.1029/2010GL045059, 2010.

Shimoda, Y., Azim, M. E., Perhar, G., Ramin, M., Kenney, M. A., Sadraddini, S., Gudimov, A., and Arhonditsis, G. B.: Our current understanding of lake ecosystem response to climate change: What have we really learned from the north temperate deep lakes?, J. Gt. Lakes Res., 37, 173-193, doi:10.1016/j.jglr.2010.10.004, 2011.

Skowron, R.: Changeability of the ice cover on the lakes of northern Poland in the light of climatic changes, Bull. Geogr. Phys. Geogr. Ser., 1, 103-124, 2009.

Soranno, P. A., Carpenter, S. R., and Lathrop, R. C.: Internal phosphorus loading in Lake Mendota: response to external loads and weather, Can. J. Fish. Aquat. Sci., 54, 1883-1893, doi:10.1139/cjfas-54-8-1883, 1997.

Stauffer, R. E. and Armstrong, D. E.: Cycling of iron, manganese, silica, phosphorus, calcium and potassium in two stratified basins of Shagawa Lake, Minnesota, Geochim. Cosmochim. Acta, 50, 215-229, doi:10.1016/0016-7037(86)90171-7, 1986.

Stauffer, R. E. and Lee, G. F.: The role of thermocline migration in regulating algal blooms, in Modeling the eutrophication process, Ann Arbor Science Publishers, Inc, Ann Arbor, MI, 73-84, 1973.

Stefan, H. G., Hondzo, M., Fang, X., Eaton, J. G., and McCormick, J. H.: Simulated long term temperature and dissolved oxygen characteristics of lakes in the north-central United States and associated fish habitat limits, Limnol. Oceanogr., 41, 1124-1135, doi:10.4319/lo.1996.41.5.1124, 1996.

Stenseth, N. C. and Mysterud, A.: Climate, changing phenology, and other life history traits: Nonlinearity and match-mismatch to the environment, P. Natl. Acad. Sci. USA, 99, 13379-13381, doi:10.1073/pnas.212519399, 2002.

Stewart, K. M.: Physical limnology of some Madison lakes, PhD Thesis, University of Wisconsin-Madison, Madison, Wisconsin, USA, 229 pp., 1965.

Tanentzap, A. J., Hamilton, D. P., and Yan, N. D.: Calibrating the Dynamic Reservoir Simulation Model (DYRESM) and filling required data gaps for one-dimensional thermal profile predictions in a boreal lake, Limnol. Oceanogr. Meth., 5, 484-494, doi:10.4319/lom.2007.5.484, 2007.
Tanentzap, A. J., Yan, N. D., Keller, B., Girard, R., Heneberry, J., Gunn, J. M., Hamilton, D. P., and Taylor, P. A.: Cooling lakes while the world warms: Effects of forest regrowth and increased dissolved organic matter on the thermal regime of a temperate, urban lake, Limnol. Oceanogr., 53, 404-410, doi:10.4319/lo.2008.53.1.0404, 2008.

Tomé, A. R. and Miranda, P. M. A.: Piecewise linear fitting and trend changing points of climate parameters, Geophys. Res. Lett., 31, L02207, doi:10.1029/2003GL019100, 2004.

Toms, J. D. and Lesperance, M. L.: Piecewise regression: a tool for identifying ecological thresholds, Ecology, 84, 2034-2041, doi:10.1890/02-0472, 2003.

Van Cleave, K., Lenters, J. D., Wang, J., and Verhamme, E. M.: A regime shift in Lake Superior ice cover, evaporation, and water temperature following the warm El Niñ winter of 1997-1998, Limnol. Oceanogr., 59, 1889-1898, doi:10.4319/lo.2014.59.6.1889, 2014.

Vavrus, S. J., Wynne, R. H., and Foley, J. A.: Measuring the sensitivity of southern Wisconsin lake ice to climate variations and lake depth using a numerical model, Limnol. Oceanogr., 41, 822-831, doi:10.4319/lo.1996.41.5.0822, 1996.

Wan, H., Wang, X. L., and Swail, V. R.: Homogenization and trend analysis of Canadian near-surface wind speeds, J. Climate, 23, 1209-1225, doi:10.1175/2009JCLI3200.1, 2010.

Wilhelm, S. and Adrian, R.: Impact of summer warming on the thermal characteristics of a polymictic lake and consequences for oxygen, nutrients and phytoplankton, Freshwater Biol., 53, 226-237, doi:10.1111/j.1365-2427.2007.01887.x, 2008.

Williams, D. T., Drummond, G. R., Ford, D. E., and Robey, D. L.: Determination of light extinction coefficients in lakes and reservoirs, in Proceedings of the Symposium on Surface Water Impoundments, Minneapolis, MN, USA, 1329-1335, 1980.

Williams, G., Layman, K. L., and Stefan, H. G.: Dependence of lake ice covers on climatic, geographic and bathymetric variables, Cold Reg. Sci. Technol., 40, 145-164, doi:10.1016/j.coldregions.2004.06.010, 2004.

Winslow, L. A., Read, J. S., Hansen, G. J. A., and Hanson, P. C.: Small lakes show muted climate change signal in deepwater temperatures, Geophys. Res. Lett., 42, 355-361, doi:10.1002/2014GL062325, 2015.

Wrona, F. J., Prowse, T. D., Reist, J. D., Hobbie, J. E., Lévesque, L. M. J., and Vincent, W. F.: Climate change effects on aquatic biota, ecosystem structure and function, Ambio, 35, 359-369, 2006.

Yan, N. D.: Effects of changes in $\mathrm{pH}$ on transparency and thermal regimes of Lohi Lake, near Sudbury, Ontario, Can. J. Fish. Aquat. Sci., 40, 621-626, doi:10.1139/f83-081, 1983.

Yeates, P. S. and Imberger, J.: Pseudo two-dimensional simulations of internal and boundary fluxes in stratified lakes and reservoirs, Int. J. River Basin Manage., 1, 297-319, doi:10.1080/15715124.2003.9635214, 2003.

Ying, L., Shen, Z., and Piao, S.: The recent hiatus in global warming of the land surface: Scale-dependent breakpoint occurrences in space and time: scale-dependent hiatus in space and time, Geophys. Res. Lett., 42, 6471-6478, doi:10.1002/2015GL064884, 2015. 